\title{
Flying-fox Heat Event Response Guidelines SEQ
}

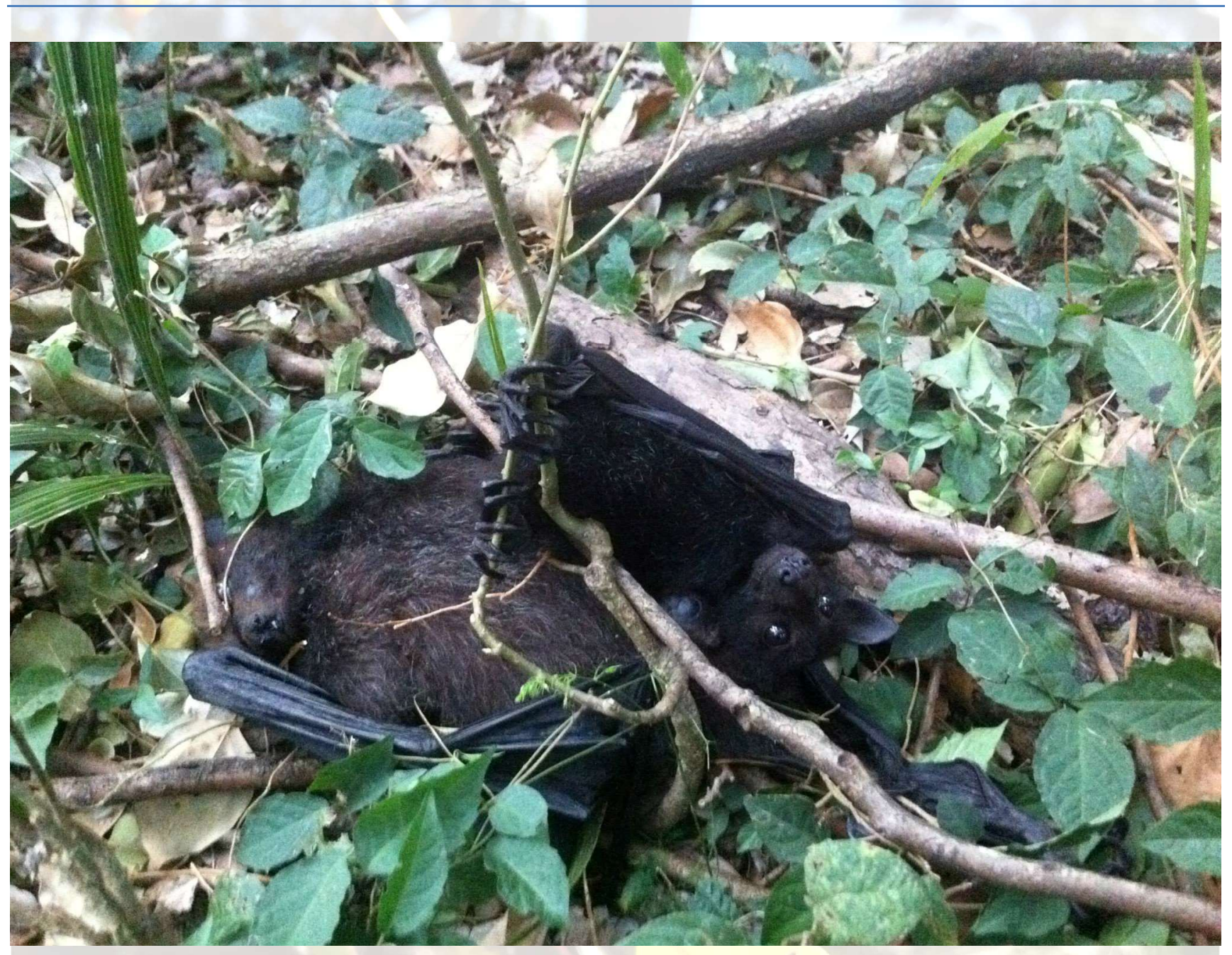

Dr. Tania Bishop BVSc (Hons1a), MANZCVS (Avian Health) Ms Rachel Lyons BRTP(Hons), GC Env. Man.

July 2018 (Ver 1) 


\section{Table of Contents}

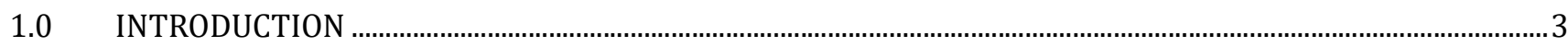

2.0 IDENTIFICATION OF HEAT STRESS EVENT (HSE) SITES............................................................................

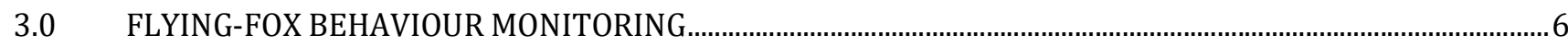

4.0 SITE MONITORING \& INFORMATION DISSEMINATION ...........................................................................

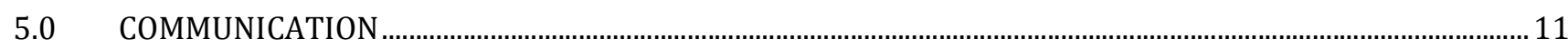

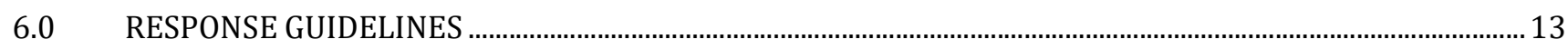

WORK PLACE HEALTH \& SAFETY - WH\&S (PHYSICAL \& EMOTIONAL) ................................................................ 19

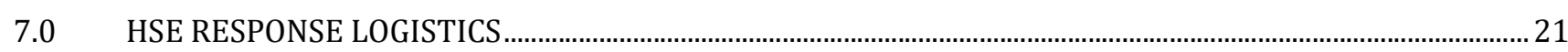

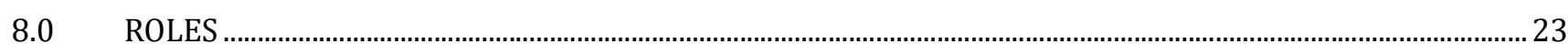

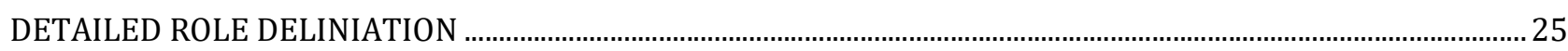

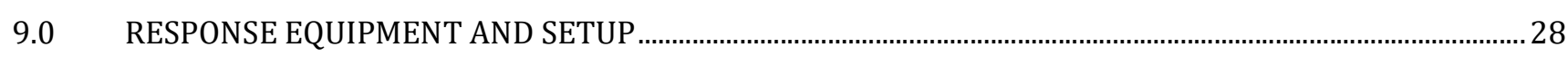

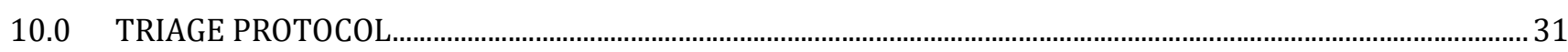

TRIAGE - ALL BATS THAT REQUIRED MOVING FROM CAMP FOR TRIAGE .............................................................. 31

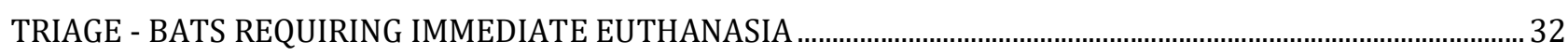

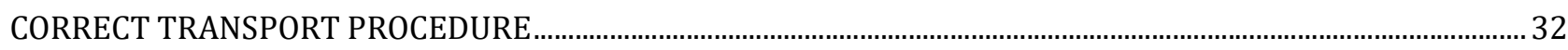

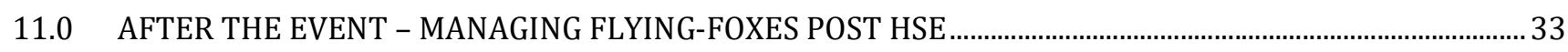

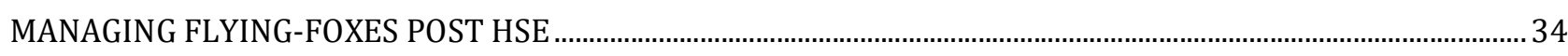

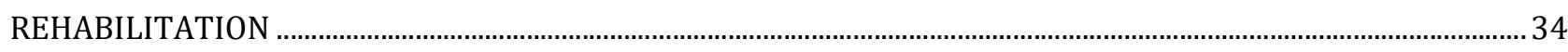

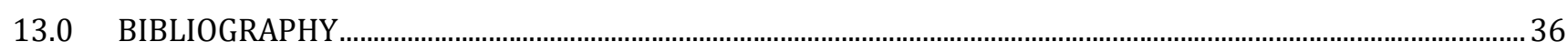

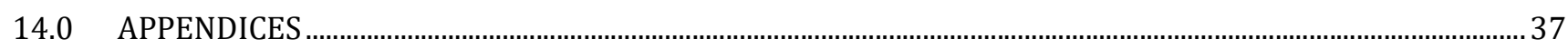

14.1 SEQ HSE CAMP STRATEGIES - GATHERED AT HSE WORKSHOP ……............................................................ 37

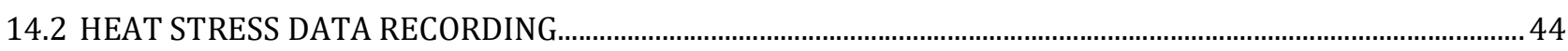

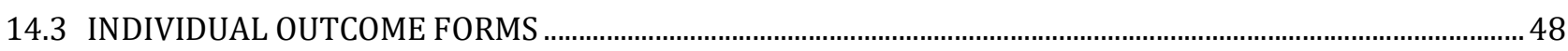

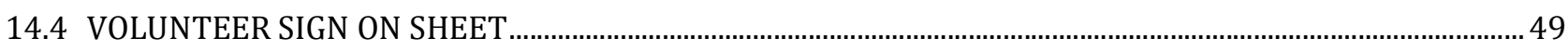

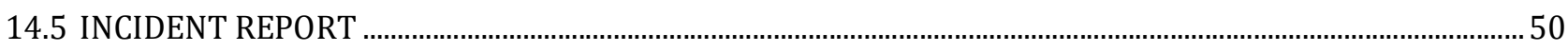

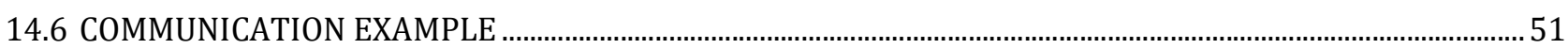

14.6 WORKSHOP QUESTIONNAIRE FOR INITIAL DATA COLLECTION ……........................................................ 52

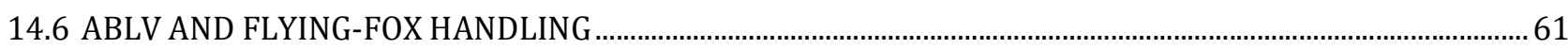

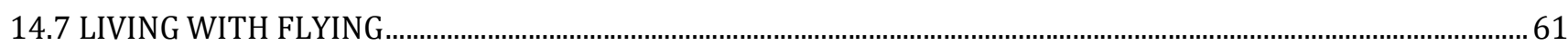

Flying-fox Disaster Response Guidelines SEQ 2018. 


\subsection{INTRODUCTION}

Flying-fox populations are increasingly threatened by heat events, starvation events and other stressors due to habitat clearing and human/flying-fox conflict.

These factors are unlikely to resolve, meaning that a well-coordinated and timely approach to flying-fox disasters is imperative for the mitigation of further flying-fox population impacts.

\section{Key Words -}

Flying-fox, disaster management, heat events, heat stress, roost management, physiology, veterinary management.

The following document aims to give a framework for all stakeholders for the prevention, preparedness, response and recovery of flying-foxes during such events.

Stakeholders who may find this document useful would include, but are not limited to:

- Land Managers

- Decision makers

- Researchers

- Conservationists

- Veterinarians

- Wildlife professionals

- Wildlife carers

The following document was created after a flying-fox heat response forum was sponsored by LGAQ and hosted by Logan City Council, convened by Mrs Lee-Anne Veage. Environment Officers, Wildlife Officers and key wildlife carers experienced in flying-fox heat event responses representing each of the key regions in the greater SEQ region were in attendance of a full day conference and workshop. The data from the questionnaire found in Appendix 14.6 was collated and utilised to form the following document.

The document was written by Dr. Tania Bishop BVSc(hons1a) MANZCVS (Avian Health) and co-authored by Ms. Rachel Lyons BRTP(Hons), GC Env. Man.

The document has been reviewed by the following people due to their key expertise in the field:

- Dr. Peggy Eby

- Dr. Alison Peel

- Mr David Zammit

- Mrs Lee-Anne Veage

Attendees at the forum contributing to data:

Rodney Adam - Environment officer - Logan City council

Tim Shields - Environment officer - Ipswich City Council

Darren McPherson - Environment Officer - Somerset Council

Jenny Davis - Wildlife Officer - Redland City Council

Lisa Bailey - Wildlife officer - Redland city council

Raeleen Draper - Wildlife officer - sunshine coast council

Glenn Miechel - Wildlife officer - sunshine coast council

Andrew Evans - Environment officer - Moreton Bay Regional Council

Martin Bennett - Environment officer - Lockyer Valley Regional Council

Robyn Jones - Wildlife Officer - Brisbane City Council

Joshua Baker - Environment Officer - Scenic Rim Regional Council

Terrie Ridgeway

Flying-fox Disaster Response Guidelines SEQ 2018. 


\author{
Michelle Chubb \\ Kerry Turner \\ Helen Mcleish \\ Sue Morris \\ Rachel Lyons \\ Keith Falkiner \\ Michael Jansen \\ Jane Shead \\ Bill Shead \\ Charmaine Brayley \\ Jade Lewis \\ Sammy Ringer \\ Byron Cann \\ Lorna Smith \\ Dee Smith \\ Linda Darcy \\ Mary Jane Robinson \\ David Zammit \\ Sharon Quinlan \\ Trish Wimberley \\ Cathy Griffin \\ Sylvia Hood \\ Carmel Givens \\ Paula Frazer \\ Michelle Morgan \\ Leanne Robinson \\ Valerie Holbeck \\ Kerry Kent \\ Nitin Pandya \\ Ashley Fraser
}

Flying-fox Disaster Response Guidelines SEQ 2018. 


\subsection{IDENTIFICATION OF HEAT STRESS EVENT (HSE) SITES}

Heat stress variables that determine the susceptibility of a roost during a heat stress event (HSE) include the following:

\begin{tabular}{|l|}
\hline Weather/Climate \\
\hline Temperature $>40^{\circ} C_{\text {SEP }}^{-} \&$ No. of consecutive days \\
\hline Humidity \\
\hline Wind direction - West and North \\
\hline Camp attributes \\
\hline Size of camp and history of prior heat events \\
\hline Camp composition - understory, mid-storey and canopy - open / closed structure - incredibly important \\
\hline Proximity to water \\
\hline Topography / aspect / altitude \\
\hline Location - westerly aspects, heat islands \\
\hline Crowding at camps \\
\hline Camp Capacity \\
\hline Human Activity and site tenure - incidental or intentional disturbance \\
\hline Other stressors for camp e.g. camp management, food shortages \\
\hline Splintering of camps \\
\hline Demographics \\
\hline Time of year - mating; pregnant lactating female, pregnant females \\
\hline Number, age and developmental stage of juveniles \\
\hline Species composition \\
\hline
\end{tabular}

During the HSE Forum held in Logan on $3^{\text {rd }}$ November 2017, a list of all prior HSE sites in SEQ was developed with information collected pertaining to Camp attributes, sensitivity, monitoring efforts and relevant contacts. This list was collated and is contained in Appendix 14.1.

Flying-fox Disaster Response Guidelines SEQ 2018. 


\subsection{FLYING-FOX BEHAVIOUR MONITORING}

Flying-fox monitoring is critically important before, during and after a response.

\section{NORMAL BEHAVIOUR (CLASSIFIED AS CATEGORY 1)}

A greater understanding of "normal" behaviour (Classified as Category 1) will aid in an understanding of abnormal behaviour so to indicate if a response is going to be required.

The time of year, ambient temperature and relative humidity should always be considered as an essential part of information when interpreting any behaviour.

The percentage (\%) and demographics of animals carrying out such behaviours are also important. i.e.; pregnant/lactating females fanning only versus the entire colony fanning. Pregnant and lactating females can start fanning at temperatures as low as $23{ }^{\circ} \mathrm{C}$ due to the higher metabolic demands of their physiological state.

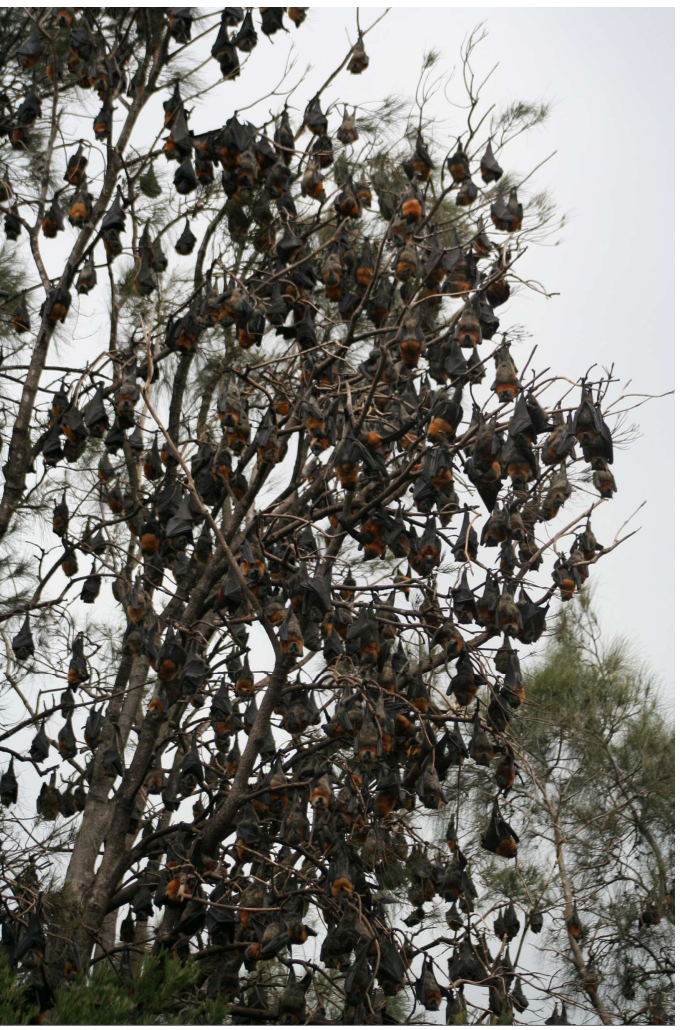
Whilst observing these behaviours is important and can act as early warning systems of arising issues, it is also important to note that these behaviours can be normal in these animals.

Behavioural progression from animals showing signs of heat stress through to heat stroke will always follow a predictable consistent progression. (Snoyman et al., 2012). This progression is as follows:

\section{WING FANNING (CLASSIFIED AS CATEGORY 2)}

- Wing Fanning is normal cooling behaviour in minor heat stress.

- It is conducted to increase the flow of cooler air over the wing membranes where the dilated blood vessels full of warmed blood can cool from radiant cooling.

- This can start at temperatures as low as $23^{\circ} \mathrm{C}-30^{\circ} \mathrm{C}$ depending on the physiological status of the individuals within the camp and the relative humidity.

- Monitoring only the numbers of bats carrying out this behaviour and any progression

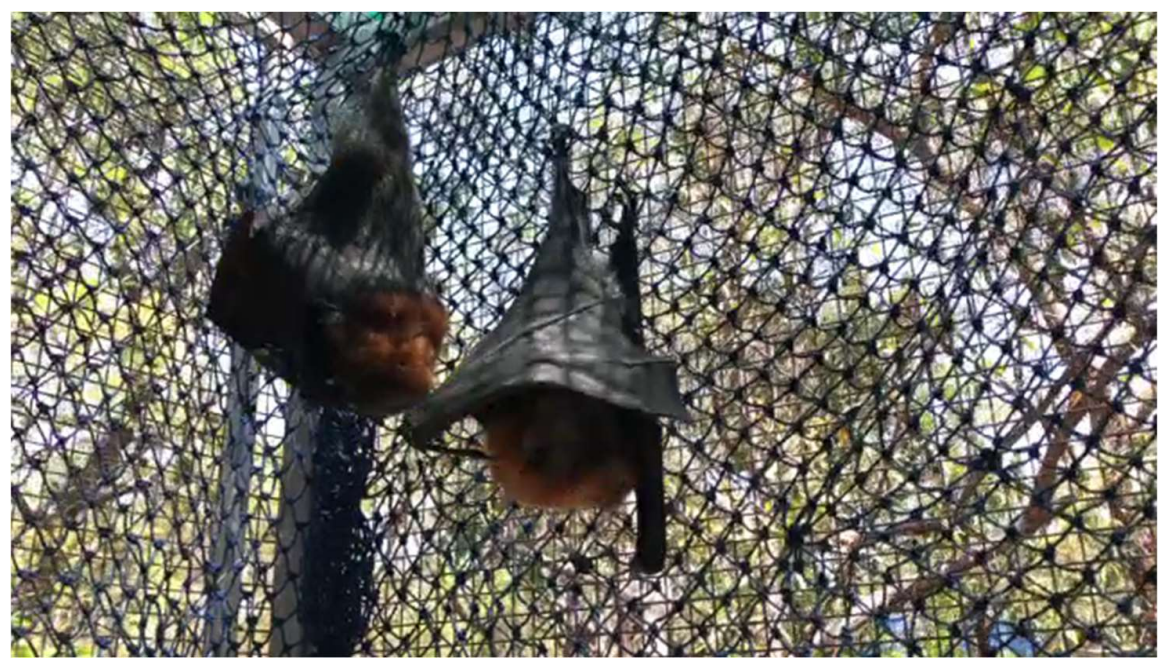
needs to be noted at this point.

Figure 2 Wing fanning

$$
\text { (1) }
$$




\section{CLUSTERING (CATEGORY 3a)}

- Bats start to move further down the trees into the middle-storey vegetation. Thermal imaging has revealed that bats are attempting to move to cooler microclimates within the camp. (Welbergen et al. 2012)

- Bats will continue to fan during this time and if temperatures continue to rise they will start panting and wrist licking.

- Whilst this stage does not immediately trigger an alert, bats starting to carry out this behaviour need to be monitored and response groups need to be placed on alert for the possible need of an on-site response.

- This behavioural stage should be posted on alert platforms and once confirmed, preparations for response should be coordinated.

It is important to note that bats at this stage should never be disturbed. Disturbance is likely to risk bats becoming stressed and taking flight, causing serious heat stroke and possible death.

\section{CLUMPING (CATEGORY 3b)}

- Flying-foxes at this stage will roost on top of each other.

- This can occur on:

- $\quad$ Shaded side of the trees

- Under logs

- The understorey

- In tree hollows

- The base of trees

- On the ground

- These clumps can consist of in excess of 50+ flying-foxes.

- At this stage flying-foxes should not yet be approached for spraying, as many would not tolerate spraying at this point.

- At this time HSE response personnel should be in place and set-up for a response, should the sensitivity of the roost, location and resources allow.

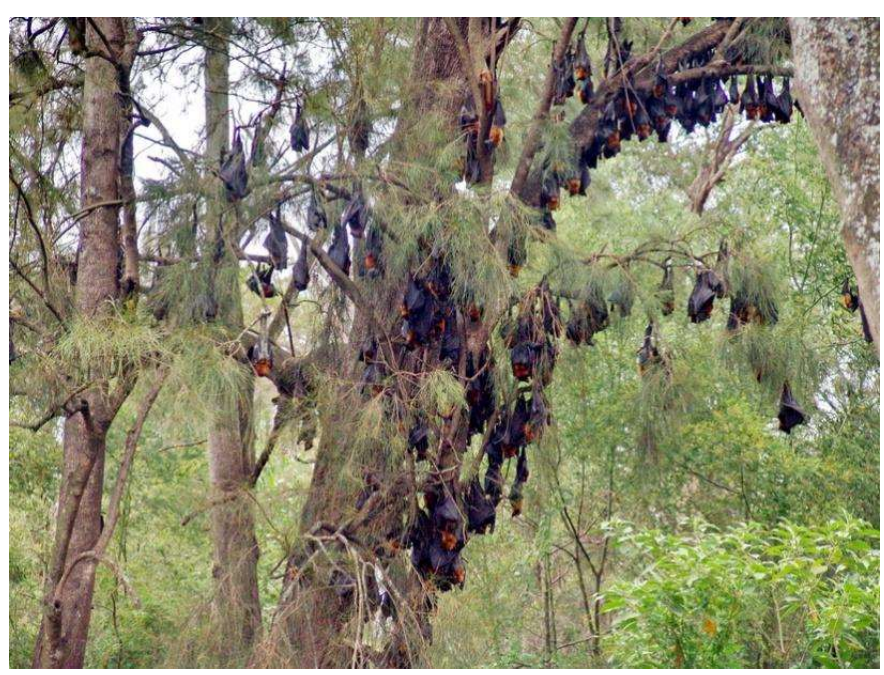

Figure 3 Clustering

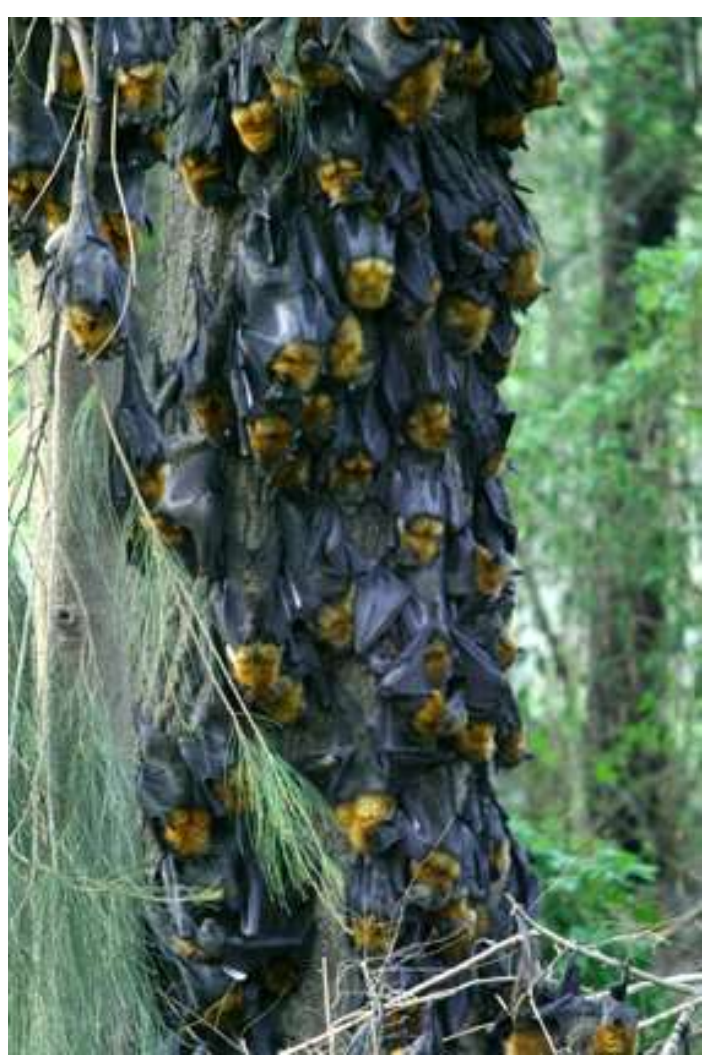

Figure 4 Clumping

Flying-fox Disaster Response Guidelines SEQ 2018. 


\section{PANTING/WRIST LICKING AT THE BOTTOM OF TREES (CATEGORY 4)}

- At this stage a response should have been triggered and a response site should already be set up ready to go, if intervention is suitable for the roost and site.

- Bats start to pant and lick their wrists. Ambient temperature has continued to rise and clumping in cooler microclimates and wing fanning has failed to lower their core body temperatures.

- Wrist licking and panting is utilised as a means of using evaporative cooling to lower core body temperatures.

- In high humidity heat events, this is hampered by high humidity affecting the ability of bodily fluids to evaporate and cool the body.

- In low humidity heat events, this will be very effective at cooling the body, however it will be

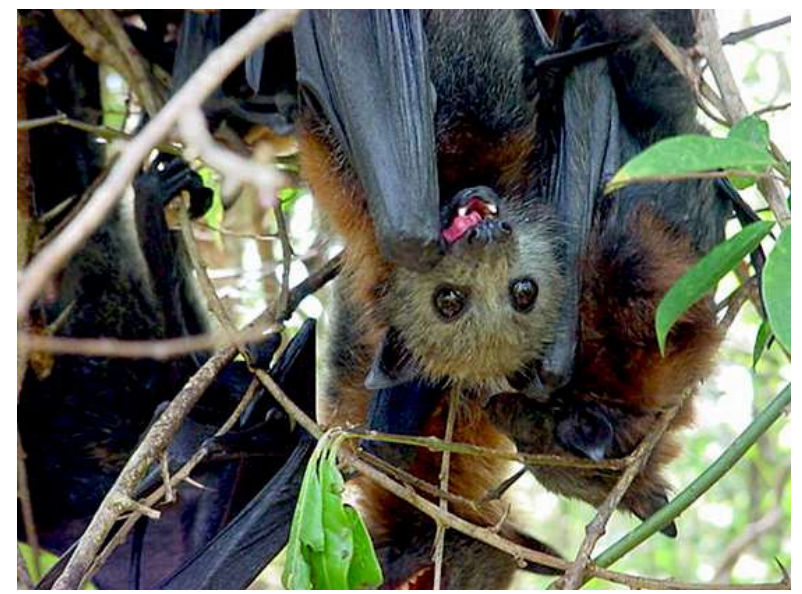

Figure 5 Wrist Licking extremely costly as flying-foxes will dehydrate very quickly.

- This is why HIGH and LOW humidity events require a different approach to spraying timing and monitoring.

- Bats will become very dehydrated and become hypoglycaemic and vague due to the effort of fanning and heat stroke starting to affect body functioning.

- Bats will move to the bottom of the trees and those with no mid-storey may fall from the upper canopy with severe heat stroke.

- At this stage, monitoring needs to be undertaken very carefully.

- Rescuers need to very cautiously approach bats at the base of trees to monitor for any signs of distress and bats trying to lift off.

- Rescuers then MUST move away as quietly as possible to avoid bats lifting at this critical stage.

- Any seizuring animals should be taken for euthanasia ONLY if a licenced carer is available AND other nearby bats are not stressed or show signs of lift on approach.

- Seizuring flying-foxes should not be removed from the camp if there is not someone licenced for euthanasia immediately present, as dying unaided in the presence of humans will be far more stressful for the animal.

- If the bats are tolerant of a quiet approach, an attempt at spraying with water and a backpack spray can be attempted.

- Start gently with the stream as a good spray...DO NOT MIST in a high humidity event, ( $>70 \%$ humidity) as this only worsens the situation through heightening humidity levels.

- Gradually increase the intensity of the spraying so that each bat gets saturated directly with water.

- Move on to observe the next area and come back and observe the previously sprayed bats after 15 minutes.

- After three (3) attempts at good spraying - those remaining bats that have not responded (i.e. climbing back into the mid-storey) should be taken for triage.

- Do not immediately remove orphans that are roosting in trees, as mothers will often come back for babies once the situation has settled. It will become apparent over the next 24-48 hours if juveniles are truly orphaned.

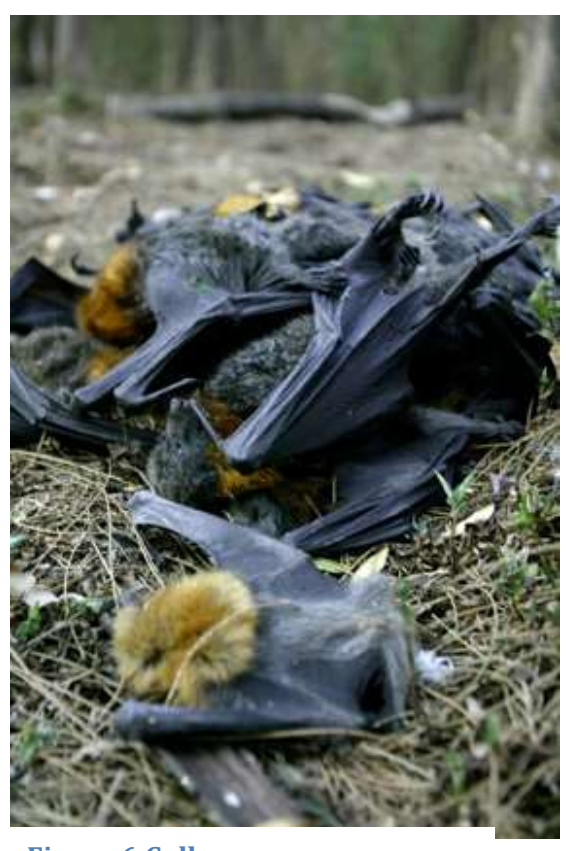

Figure 6 Collapse 
- Ideally all bats brought in for triage should be seen at a wildlife veterinary facility, as all of them will have systemic damage due to heat stroke which can only be addressed adequately and humanely with intensive veterinary treatment. 


\subsection{SITE MONITORING \& INFORMATION DISSEMINATION}

- At the Logan HSE Forum, there was consensus of the need for monitoring camps at regular intervals throughout the year to gain a better understanding of specific camp behaviour. Understanding normal behaviours of camps help to understand when abnormal behaviours are occurring. Monitoring of camps in the lead-up, during and after events is necessary.

- The Logan Forum attendees discussed the need for more teams to be educated in reading camp and flying fox behaviours.

- The Logan Forum attendees identified the need and moved to establish a 'SEQ Disaster Management' Facebook page with strict terms of reference and for regional coordination of events, education and admin scrutiny of posts. It is located at the following link https://www.facebook.com/groups/187708728487898/

- Other tools are available to help monitor weather outlook, current temperatures, potential heat stress events forecasting and flying-fox roost information:

- Bureau of Meteorology (BOM) http://www.bom.gov.au/

- Flying-fox Heat Stress Forecaster https://www.animalecologylab.org/ff-heat-stress-forecaster.html

- Weather zone http://m.weatherzone.com.au/

- National Flying Fox Monitoring Viewer http://www.environment.gov.au/webgisframework/apps/ffc-wide/ffc-wide.jsf

- Looking forwards, the Forum attendees identified that it would be ideal to gain funding to obtain:

- Data loggers (temperature and humidity) in camps -

- Remote cameras in camps to enable remote behaviour monitoring; and

- Regular personnel to monitor flying-fox roosts

- Pre-event heat event triage and trauma care training for consistency in approach

- Orphan and adult flying-fox care with an emphasis also on disaster management and triage consistent across all carer groups.

- Consistent handling and safety training across all groups 


\subsection{COMMUNICATION}

There is a clear need to enhance the communication of HSE's both within the rehabilitation and rescue networks but also more widely in the local community.

Multiple flying fox rescue groups exist in SEQ and a multitude of sites effected by HSE exists which can create difficulties and inefficiencies in resources where communication is lacking.

\section{FACEBOOK COMMUNICATION SITE}

A Flying Fox Disaster Management Forum Facebook Group was identified within the Logan 2017 HSE forum as being a useful tool to enhance communication within the operational response groups.

https://www.facebook.com/groups/187708728487898/

The Facebook group is established to "aid in response coordination and information dissemination related to Flying Fox Disaster Management, including heat stress events, starvation events, storm events and any other event involving multiple camps and/or flying foxes."

The group will operate as per the following points which were proposed at the Logan Forum:

- Have a rotation of Council officers acting as site moderators.

- Include standardised communication leaflets to use in disaster events.

- Store relevant information / protocol / documentation.

- Real time videos of behaviours can be uploaded and consensus can be made on whether a response is required or further monitoring.

- Allows for structural framework support for disaster management PPRR - prevention, preparedness, response and recovery.

- Ensure that information is standardised and correct for media and community information.

- Debriefing events post disasters, to offer support and fine-tune responses for future events.

- Identify training requirements. Responses and triage are very varied with considerable variation between groups.

- Training on camp monitoring and bat behaviour identification associated with disaster responses.

- Training on smooth coordination, role defining and deployment of resources in a disaster event.

- Allow dissemination of information about 'at-risk' camp activity and the need to deploy resources and/or people to affected areas.

\section{MEDIA AND COMMUNITY}

Various options exist for general community awareness raising of HSE's. These include:

- Pre-prepared standardised statements or flyers to physically letter-box drop with a list of key message points, so that correct and consistent information is disseminated to the community and/or media. It is important that common messages of communication are used.

- Local bat rescuer getting to know locals as well as foster links with local government.

Examples of strategies in action include:

- Standardised media releases and letter box drops - Refer Appendix 14.5 - community letter box drop flyer.

- Door to Door approaches to local community directly affected by HSE.

- Bi-monthly community newsletter - 'camp neighbours' - e.g. Sunshine Coast Regional Council.

- Distribute the Living with Flying-fox brochure.

Flying-fox Disaster Response Guidelines SEQ 2018. 
- Call centre scripting (including after hours) for Council's - Ipswich City Council update call centre scripting - business hours.

- Information signs at colonies with contact details for site coordinator/ rescue group/s; including temporary corflute signs at key times. - i.e. have pre-prepared corflute signs that are erected at camps during HSE peak times with information and contact numbers. Needs to be organised with local council.

Care must be taken regarding media contact protocols, particularly involving Council Officers.

With regards to media content, have pre-planned media statements or key points to get across so to stay on message. Appoint a Media Spokesperson who is not in the hot zone, preferably a person that is in charge and is not in the thick of the rescue, so they can be objective and look professional in the media to instil confidence in public.

Any media information needs to focus on the environmental and economic value of flying-foxes, as well as the human aspect, whilst also addressing any health concerns that members of the public may have.

Reinforce the existence of Flying-fox local networks and show the community that there are plans in place to both help the bats and protect the community and that Groups and Local Government are on the same page.

\section{GENERAL COMMUNICATION BETWEEN OPERATIONAL RESPONDERS}

Various stakeholders exist at roost sites and during HSE's. The following table is a guide to identify stakeholders who should be informed and/or included with options on methods of contact and suggested timeframes.

\begin{tabular}{|c|c|c|}
\hline Who & How & When \\
\hline $\begin{array}{l}\text { Landholder, } \\
\text { local resident, } \\
\text { local business }\end{array}$ & $\begin{array}{l}\text { Letter box drop flyer / Phone / } \\
\text { Email/ Verbal site visit. Get } \\
\text { alterative contacts if land owner is } \\
\text { not available }\end{array}$ & $\begin{array}{l}\text { Pre / leading up to an Event (set up } \\
\text { triggers i.e. Temp is predicted to hit .... In } \\
\text { this location on this day etc }\end{array}$ \\
\hline $\begin{array}{l}\text { Resource Providers } \\
\text { (E.g. water trucks etc) }\end{array}$ & $\begin{array}{l}\text { Phone / Email / name and address } \\
\text { of company }\end{array}$ & $\begin{array}{l}\text { Pre / leading up to a HS Event (set-up } \\
\text { triggers) i.e. Temp is predicted to hit .... } \\
\text { In this location on this day etc... (? Water } \\
\text { truck availability, access issues) }\end{array}$ \\
\hline $\begin{array}{l}\text { Wildlife Carer Groups } \\
\text { \& Support People }\end{array}$ & $\begin{array}{l}\text { Phone / Email/ Social media / } \\
\text { Groups internal coms network } \\
\text { (private FB \& Chat groups etc ) }\end{array}$ & $\begin{array}{l}\text { Pre / leading up to an Event (set up } \\
\text { triggers i.e. Temp is predicted to hit .... In } \\
\text { this location on this day etc }\end{array}$ \\
\hline Wildlife Hospitals & Phone / Email / Address & Leading up to an Event \\
\hline $\begin{array}{l}\text { Reporting - HSE } \\
\text { Website, Local } \\
\text { Councils etc }\end{array}$ & Phone / Email & $\begin{array}{l}\text { During and After Event } \\
\text { Ideally Pre / leading up as some Councils } \\
\text { can assist in releasing a public FB post }\end{array}$ \\
\hline
\end{tabular}

Table 1. Identified stakeholders and methods of communication for pre, during and post HSE

On site coms via mobile phone (delegate one phone number as a point of contact for the site with a back-up number) this will preferably be someone who is in charge of signing people on, Logistics etc and if available UHF (CB) Radios and Runners/ messengers to communicate with the rescue site. It is also recommended, to have in the sign-on area, white boards or some sort of notice board to provide basic information. 


\subsection{RESPONSE GUIDELINES}

Below is an overview of the process in response to a flying-fox disaster using the PPRR methodology relating to Prevention, Preparedness, Response and Recovery. This is then followed by detailed information on each section for further reference and guidance.

The HSE Forecaster may provide a few days notice as to a potential heat stress event, so a large part of a successsful response is preparation. If a HSE is predicted and the decision is made to respond, then clear criteria based on the environmental conditions, roost characteristics and the progression of the bats' behavioural responses to the heat on the day, will determine the timing of intervention. It needs to be recognised that it is not likely possible to save every bat on the day and a triage plan should be followed to achieve the ultimate aim: to minimise flying-fox suffering and deaths.

\section{PREVENTION}

- Ensure that camp vegetation structure is as intact as possible, having canopy, mid-storey and lower/understorey vegetation as a refuge. Undertake vegetation rehabilitation to improve this where required.

- Aim to maintain camp vegetation structure where possible when any vegetation management plans are formulated.

\section{PREPAREDNESS}

- Ensure that carers are well versed in flying-fox behaviour.

- Know local colonies. - consider having personnel assigned to regular monitoring of camps during the year to get to know the camps behaviours.

- Regularly and carefully monitor weather forecasts and camps

- Ensure that carers are aware of plans in advance and have all the information on response plans, communication chains and locations of resources in advance of any issues arising.

- Ensure good communication channels exist to disseminate information.

- Facebook communication site - ensure that all relevant plans and triage templates are readily available and information can be efficiently and easily disseminated should an issue arise. This may assist in coordinating volunteers monitoring camps.

- Ensure that all community and media information is correct and standardised to facilitate the consistent and correct information being provided to the general public on what is happening as soon as possible, or in the lead up to a possible event.

- Contact your local Council Wildlife/Environment Officer to inform/advise of potential activities. This is also useful in the event the Council has trained and available staff to assist in HSE preparedness and response.

- Ensure that the location of any resources is known, maintained and stocked correctly.

- Roles are clearly defined and the contact details of members involved in specific roles is easily accessible.

- Paperwork for data collection including site- induction sheets, tag numbers and bat details are all ready and stored with triage and rescue equipment in advance. Refer Event Data forms provided in Appendix 14.2 and 14.3 .

- Ensure that all recording paperwork is standardised so that it can be compiled in the event of a multilocation disaster.

- Ensure that maps including access points to camps are available to everyone (FB site) - include UBD references, address, and GPS coordinates, mud maps.

- Have a standardised mud map of each known susceptible colony in advance with the locations for best set-up of a triage area and a list of available nearby resources in advance - e.g.; evacuation points in the

Flying-fox Disaster Response Guidelines SEQ 2018. 
event of a bushfire; triage locations; division quadrants in the roost; volunteer resting area away from triage; signage locations; sign-in/out locations etc.

- Triggers for monitoring, responding and recovery stages - E.g. Heat Stress Forecaster website has indicated a high risk - discuss need to respond on Flying-fox Disaster Facebook site and trigger response.

- List of close-by facilities - wildlife hospitals, vets that have vaccinated staff and are happy to take flyingfoxes, service stations, hospitals (human), shops (for welfare, consumables, gloves, ice), and local government.

- The HSE plan should be scalable from a 1 day to a multi-day event.

- Have role responsibility guidelines so groups can work out who is rescuing, transporting, working in triage, caring off site, who will replace the first wave of rescuers in a multi-day event etc.

- Have reliable links for information like BOM, Met-eye (also has a user-friendly interface), local FB pages, Local Government.

- Have up to date contacts for Local Government, land holders happy to allow access, local and nearby bat groups /rescuers / carers.

- Risk assessment and fatigue management guidelines including a roster system to allow rotation in the event of the incident scaling up to a multi -day.

- Transport protocols, container types, transport danger signs, who should transport, how to "package " the Bats in the vehicle whilst transporting them safely to the hospital or off-site carer. 


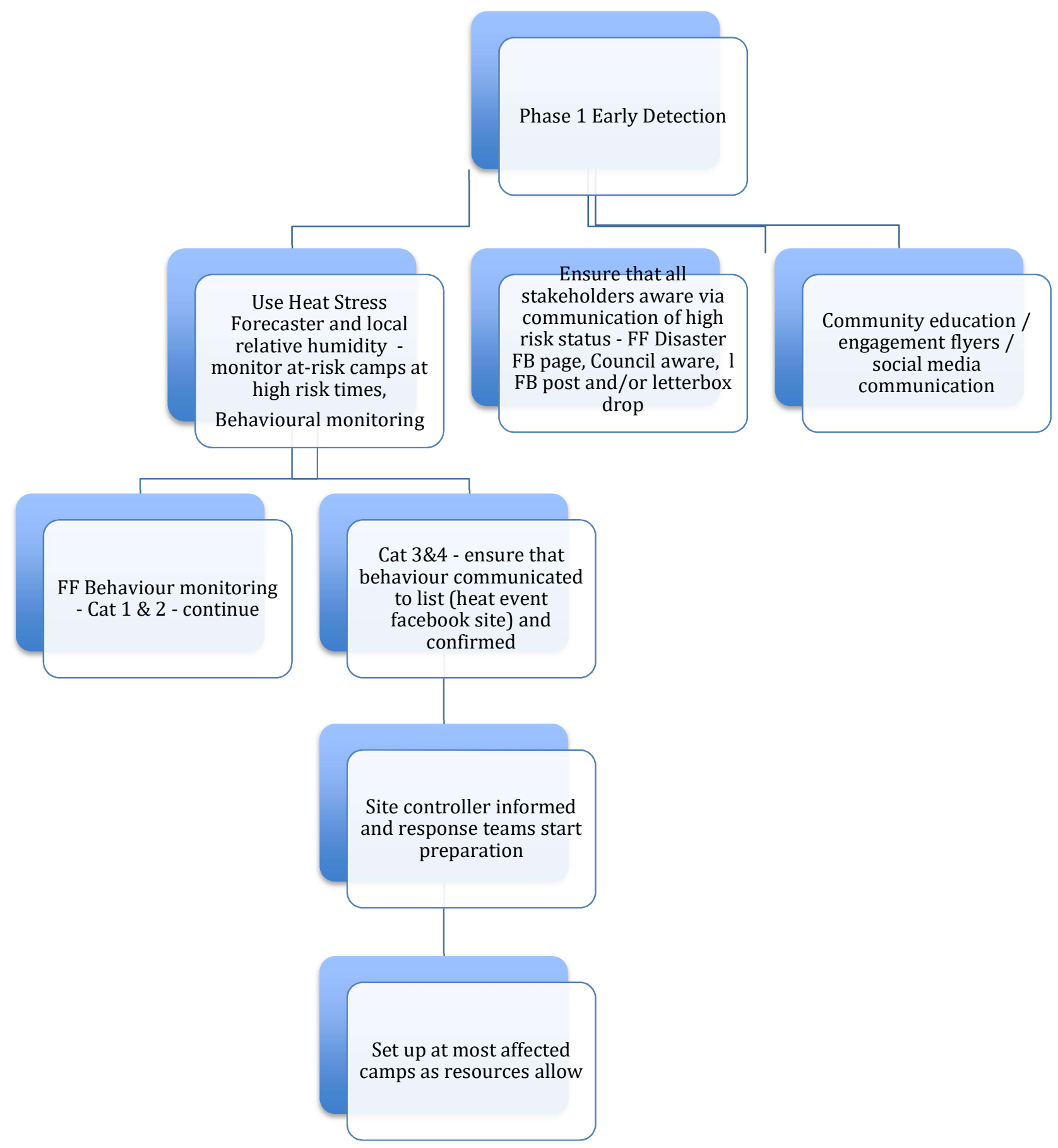

Figure 7. Flow chart of a prepared response to a HSE 


\section{RESPONSE}

The ability and timeliness of responses will depend on the sensitivity of the camp, availability of resources, environmental and site conditions.

The monitoring of flying fox behaviour is essential to determine appropriate and relative scale of responses.

- Inform local Council contact. - some councils will have an approved response team to aid with public engagement and information.

- Ensure that public communication has occurred in lead up to event - if signs indicate a need to respond, ensure that all equipment boxes have been audited and are completely stocked and that communication with all stakeholders both direct and via social media has occurred. Carry out public communication methods.

- Once confirmed that a response is to occur - establish personnel available to attend.

- Site controller to co-ordinate communication with personnel in each role and trigger communication.

- Site should be set up as per the protocol of logistics on site.

- Roles should already have been established.

The following behavioural guide (Table 2) and decision support tree (Figure 8) will assist in the deliberations of a HSE intervention:

\begin{tabular}{|c|c|c|}
\hline \multicolumn{2}{|c|}{ Behaviour } & \multirow{2}{*}{$\begin{array}{l}\text { Response } \\
\text { Observe }\end{array}$} \\
\hline Cat 2 & Wing fanning & \\
\hline Cat $3 a$ & Shade seeking & Observe \\
\hline Cat 3a & Clustering & Observe / prepare for possible response \\
\hline \multirow[t]{3}{*}{ Cat $3 b$} & Clumping/ Licking & Observe / prepare \\
\hline & Salivating & Observe / prepare \\
\hline & Panting & Observe / prepare \\
\hline \multirow[t]{4}{*}{ Cat 4} & $\begin{array}{l}\text { Bats on ground / } \\
\text { disorientated }\end{array}$ & $\begin{array}{l}\text { Observe in sensitive camps. (those with flighty / stressy flying-foxes) } \\
\text { In tolerant camps - Direct spray } 3 \text { times with } 15 \text {-minute intervals. } \\
\text { Retrieve to treat only if vet or euthanasia carer is on-site, leave in-situ if } \\
\text { not. }\end{array}$ \\
\hline & Falling from trees & $\begin{array}{l}\text { Observe in sensitive camps. } \\
\text { In tolerant camps - Direct spray } 3 \text { times with } 15 \text {-minute intervals. } \\
\text { Retrieve to treat only if vet or euthanasia carer is on-site, leave in-situ if } \\
\text { not. }\end{array}$ \\
\hline & Seizing / non-responsive & $\begin{array}{l}\text { Observe in sensitive camps. } \\
\text { In tolerant camps - Retrieve only if euthanasia carer is on-site, leave in- } \\
\text { situ if not. }\end{array}$ \\
\hline & Deceased & $\begin{array}{l}\text { Observe and monitor. } \\
\text { Leave if possible for several days if a lactating female is dead. Pups are } \\
\text { known to come down to rest with deceased mother several days after } \\
\text { dead, making live pup retrieval easier. }\end{array}$ \\
\hline
\end{tabular}




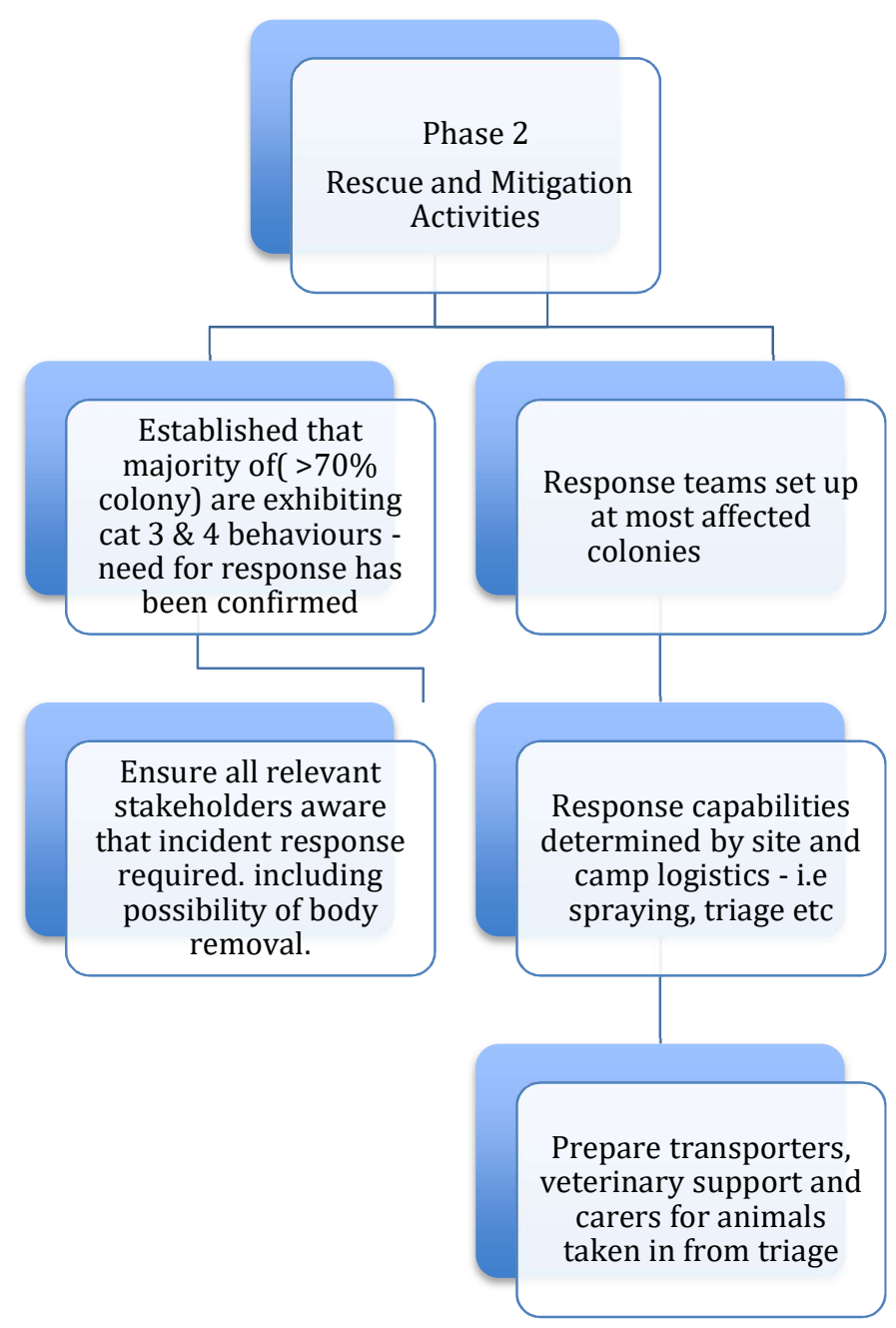

Figure 8. Response flow chart to a phase 2 Rescue and Mitigation HSE 


\section{RECOVERY}

Both Incident Debriefing and Data Collection are essential if we are to collectively learn from events and improve our practices into the future.

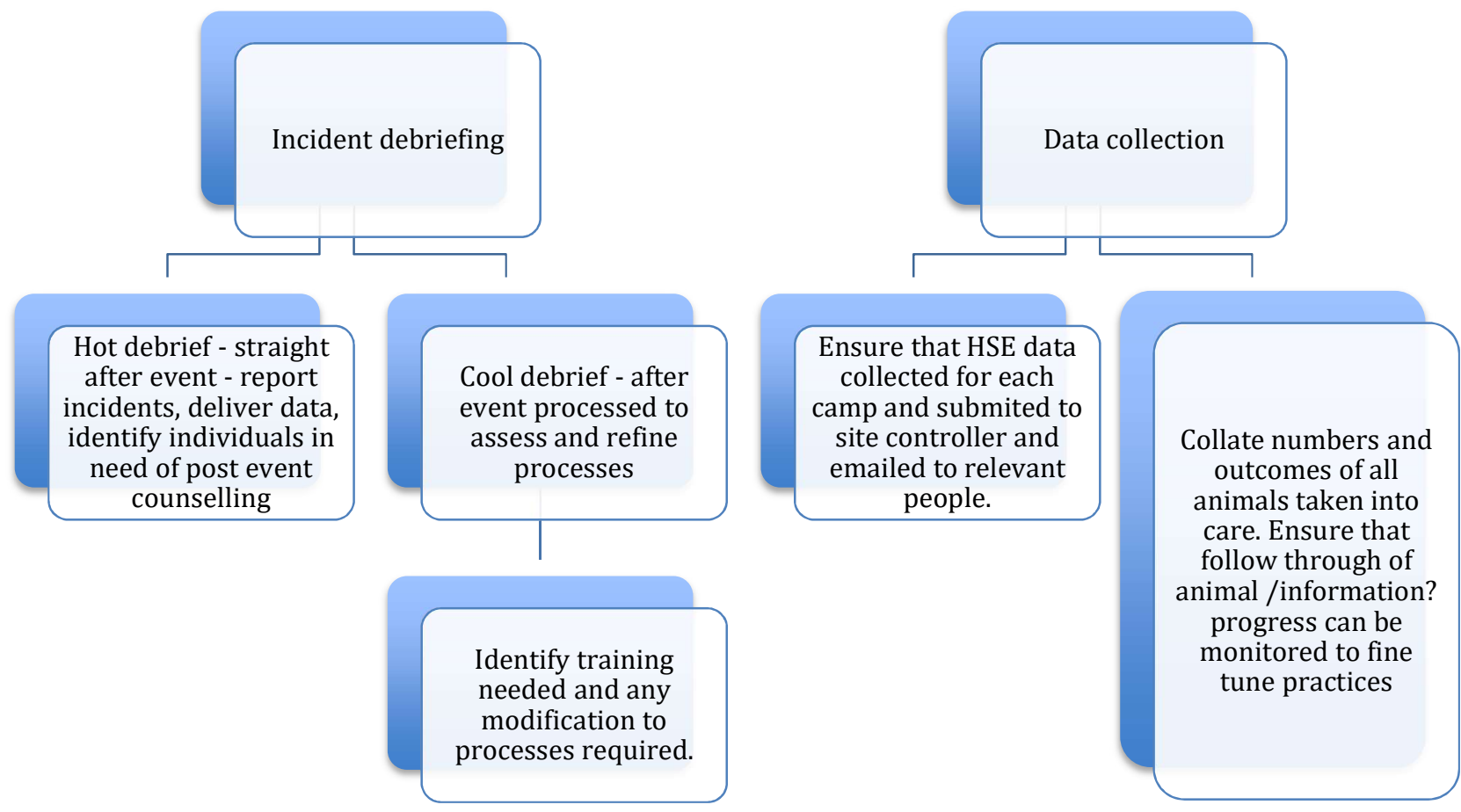

Figure 9. Recovery

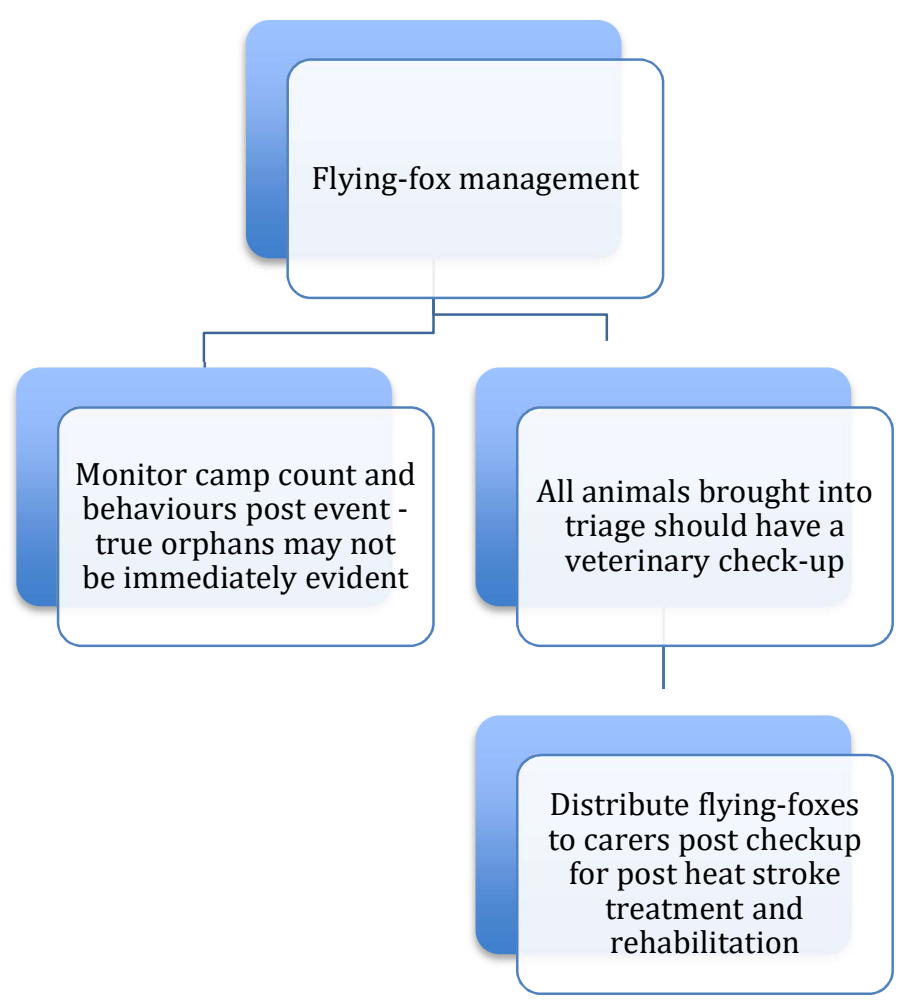

Figure 10. Flying-fox management flowchart

Flying-fox Disaster Response Guidelines SEQ 2018. 


\section{RESPONSE}

- Veterinary treatment and sending any bats taken in for triage to carers - document progress and outcomes for these bats including all relevant medical data need to be collated in order to later refine responses and follow up on success of post treatment bats.

- All post HSE orphans also need close follow-up and data on growth rate and health issues through care.

- Any bats found dead or alive with bands attached need to be reported to http://www.environment.gov.au/science/bird-and-bat-banding/get-involved/report-band-sightings

- Any bats with radio-tracking collars need to be reported also. (details should be on the radio tracker).

- Hot and cold debriefs - can be an SEQ wide event if a HSE has occurred at multiple sites - Correct information collected

- Facilitates emotional support of those involved;

- Allows analysis of techniques that worked, did not work and how procedure can be modified and/or improved;

- Also allows evaluation of response - in cold debriefs - was protocol carried out? Was it effective? What could be changed or improved?

- Ensure, you take the time to review and ask if there were there other factors involved which caused that particular camp to be more susceptible? Can anything be done to avoid that in the future? E.g. camp rehabilitation.

- Data should be collected using the form located in Appendix 14.2 and 14.3, and the completed forms sent to the individuals listed on the form in addition to the carer group and Local Council where requested.

\section{WORK PLACE HEALTH \& SAFETY - WH\&S (PHYSICAL \& EMOTIONAL)}

What WH\&S Procedures need to be in place?

- WH\&S, induction; triage parameters; transport and media / public information standardised across camps.

- Ideal to pursue opportunities for Collective / Shared Workplace/Occupational Health \& Safety Policies and Procedures between Groups.

- HSE's should be viewed as 'Incidents' - Treat events as 'Incidents' with a formal Incident Controller.

- Each rescue / response will vary based on camp logistics.

- Ensure that anyone handling bats is vaccinated and is easily identified. Responders having copies of vaccination certificates handy in printed form or copies on their phone can do this. Groups should have a list of vaccinated people and copies of proof that they are up to date with vaccinations. One option is having simple armbands in certain bright colours for vaccinated and non-vaccinated personnel so they can be utilised more effectively.

- Rescuers tagging bats with toe tags will also help with identification of bats if a scratch or bite occurs.

- Have dedicated personnel, who are there to look after the rescuers welfare, someone who can stand back and watch the responders and identify anyone who needs to take a break, hydrate etc. This can be the same person who acts as a Safety Officer, First Aider; Organiser of personnel on that site etc. And should be someone who is not doing hands-on rescue.

- Rescuer's welfare to be aware of: emotional fatigue, physical fatigue and heat exhaustion.

- Support the people involved by providing a breakout area and have someone who is away from the rescue site who checks on them and acts as a peer supporter.

For roosts located on Council reserves, Council WH\&S requirements for operations on Council Property may apply which may include Inductions, Safe Operating Procedures, Toolbox Talks etc. Speak to your local Council Wildlife or Environment Officer contact for more information.

\section{HSE's are stressful and emotive. The emotional toll on all parties responding to a heat event is grossly} underestimated.

Flying-fox Disaster Response Guidelines SEQ 2018. 


\section{How best to support the people involved in these events:}

- Briefings pre and post events - hot and cold debriefs - Hot debriefing allows data collection and all pertinent, immediate information to be exchanged whilst still fresh in people's minds. Cold debriefing allows review of the responses after processing has occurred, to discuss outcomes and where procedures can be improved / modified.

- Ensure that grief counselling or general counselling is available to those that need it.

- Assistance in talking to people who may require counselling but may not be able to identify it.

- "Drills" to help rescuers feel prepared and emotionally ready for the event. 


\subsection{HSE RESPONSE LOGISTICS}

Each camp is unique, however the HSE operative should be the same. What on-site features need to be identified at a HSE site? What resources and equipment needs to be on standby? How do we enact their availability?

\begin{tabular}{|c|c|c|}
\hline Feature & Details & Enaction \\
\hline $\begin{array}{l}\text { Site Access } \\
\text { Permission \& } \\
\text { Landholder Support }\end{array}$ & $\begin{array}{l}\text { Access approval (best arranged pre-event), } \\
\text { identification of any existing Planning and } \\
\text { Response documentation (E.g. Moreton Bay } \\
\text { Council's) }\end{array}$ & $\begin{array}{l}\text { Obtain maps / mud maps of all } \\
\text { camps to identify these and logistics } \\
\text { of responses }\end{array}$ \\
\hline Access Logistics & $\begin{array}{l}\text { Locked gates, parking, footpaths or tracks, no- } \\
\text { go zones, maps/ fences }\end{array}$ & $\begin{array}{l}\text { Obtain maps / mud maps of all } \\
\text { camps to identify these and logistics } \\
\text { of responses } \\
\text { - } \quad \text { each group to take mud map } \\
\text { and using triage logistics } \\
\text { prepare a plan including site } \\
\text { controller position and sign on, } \\
\text { any barriers to protect MOP, } \\
\text { information signage, } \\
\text { evacuation points, triage setup } \\
\text { - identify local amenities }\end{array}$ \\
\hline Health and safety & $\begin{array}{l}\text { Needs to be identified in roles - under } \\
\text { induction / site controller and first aid officer } \\
\text { Headquarters / operative tent, inductions, sign } \\
\text { in-out sheets, first aid, drinking water, shade, } \\
\text { wash station, PPE. } \\
\text { Sanitary amenities. } \\
\text { Any amenities? Part of any pre-plan for a } \\
\text { rescue site is to ID amenities close by like } \\
\text { Shopping centres, service stations , Private } \\
\text { residences } \\
\text { Evacuation points }\end{array}$ & $\begin{array}{l}\text { See Appendix } 14.7 \text { \& pg. } 16 \\
-\quad \text { HSE Roles } \\
\text { See Templates - Appendix 14.2, } \\
\text { 14.3, } 14.4 \\
\text { - Induction site form } \\
\text { - } \quad \text { Data } \\
\text { - } \quad \text { Camp monitoring - number, } \\
\text { species and behaviour } \\
\text { recording }\end{array}$ \\
\hline Infrastructure & Water, power, shade structures, toilets. & \\
\hline Resources & $\begin{array}{l}\text { backpack sprayers, water trucks. } \\
\text { Marquee, shade structure, trestle tables }\end{array}$ & $\begin{array}{l}\text { If available to site, assess in advance } \\
\text { and enact use as soon as possible } \\
\text { after response initiated. } \\
\text { Care with use of generators and } \\
\text { noise involved stressing bats. }\end{array}$ \\
\hline Rescue and care & $\begin{array}{l}\text { Triage area, rescue / transport access and } \\
\text { process } \\
\text { Rescue Equipment - cages, poles/nets, wraps. } \\
\text { See Following Sections in this plan } \\
\text { TRIAGE - Setup, Equipment and Roles }\end{array}$ & $\begin{array}{l}\text { See following sections in this plan: } \\
\text { See pg. } \mathbf{3 0}-\mathbf{3 3} \\
\text { - } \\
\text { - } \\
\text { SRIAGE PROCEDURES } \\
\text { EQUIPMENT } \\
\text { - } \\
\quad \text { RESCUE AND RECOVERY } \\
\quad \text { PROCEDURES }\end{array}$ \\
\hline
\end{tabular}

Flying-fox Disaster Response Guidelines SEQ 2018. 


\begin{tabular}{|l|l|l|}
\hline & & \\
\hline Drivers & $\begin{array}{l}\text { Animals to wildlife hospitals / carers } \\
\text { - Can also deliver supplies needed for wildlife } \\
\text { rescue as well as items needed to support } \\
\text { responders. E.g.; additional water, food etc. }\end{array}$ & $\begin{array}{l}\text { Have on standby when HSE are } \\
\text { predicted and inform when } \\
\text { responses initiated. }\end{array}$ \\
\hline $\begin{array}{l}\text { Receiving Sites / } \\
\text { Treatment Facilities }\end{array}$ & Veterinarians / Wildlife Hospitals on standby & $\begin{array}{l}\text { Have on standby when HSE are } \\
\text { predicted and inform when } \\
\text { responses initiated. }\end{array}$ \\
\hline Rehabilitators & $\begin{array}{l}\text { Carers to receive animals after Veterinary } \\
\text { assessment and treatment }\end{array}$ & $\begin{array}{l}\text { Tracking of animals post heat stress } \\
\text { treatment } \\
\text { - See template post response data. }\end{array}$ \\
\hline Body Disposal & Landholder and/or Council involvement & Request \\
\hline $\begin{array}{l}\text { Existing } \\
\text { Documentation }\end{array}$ & $\begin{array}{l}\text { Create a template based on information } \\
\text { included adapted to your camp and group }\end{array}$ & Prepare in advance \\
\hline
\end{tabular}




\subsection{ROLES}

Successful HSE responses require many and varied roles requiring differing skill and fitness levels. Roles can include:

\begin{tabular}{|c|c|c|}
\hline Roles & Responsibility & $\begin{array}{l}\text { Who? (e.g. Council, carers, vets, } \\
\text { community, business) }\end{array}$ \\
\hline Coordination & $\begin{array}{l}\text { Coordinators from each different region - } \\
\text { utilise Facebook page to mobilise and } \\
\text { direct help where most needed }\end{array}$ & $\begin{array}{l}\text { Carers } \\
\text { Senior members who have done some } \\
\text { training or have a good understanding } \\
\text { of a HSE } \\
\text { See page } 24\end{array}$ \\
\hline $\begin{array}{l}\text { Colony } \\
\text { monitors }\end{array}$ & $\begin{array}{l}\text { Get to know camps regularly - i.e. maybe } \\
\text { quarterly checks to get to know nature of } \\
\text { camps and normal behaviour } \\
\text { Local Group / rescuers / carers or Local } \\
\text { Gov. }\end{array}$ & $\begin{array}{l}\text { Carers / council wildlife officers / } \\
\text { local MOP with an interest } \\
\text { Senior members who have done some } \\
\text { training or have a good understanding } \\
\text { of a HSE }\end{array}$ \\
\hline Communication & $\begin{array}{l}\text { Facebook page / trigger disaster event / } \\
\text { message from Facebook page out to } \\
\text { relevant people } \\
\text { Local Group / rescuers / carers or Local } \\
\text { Gov. }\end{array}$ & $\begin{array}{l}\text { Carers, area coordinators / council } \\
\text { wildlife officers } \\
\text { Senior members who have done some } \\
\text { training or have a good understanding } \\
\text { of a HSE } \\
\text { See page } 24\end{array}$ \\
\hline $\begin{array}{l}\text { Set up and pack } \\
\text { up }\end{array}$ & $\begin{array}{l}\text { Local Group / rescuers / carers and Local } \\
\text { Gov. } \\
\text { Have pre-prepared list of all equipment } \\
\text { required at a disaster event and where it } \\
\text { will be stored with a brief mud-map of } \\
\text { how it should be set up for differing } \\
\text { events. Keep a stocktake of what is there } \\
\text { and replenish used items }\end{array}$ & $\begin{array}{l}\text { Carer / vaccinated or non-vaccinated } \\
\text { Support personnel } \\
\text { See page } 24 \& 29 \text { nel }\end{array}$ \\
\hline Safety officer & $\begin{array}{l}\text { Safety officer could be site coordinator / } \\
\text { induction person -would be best if safety } \\
\text { officer and human first aid were together } \\
\text { - Local Group / rescuers / carers or } \\
\text { whoever is responsible for the } \\
\text { land the colon is on i.e. local Gov, } \\
\text { will need to appoint one. }\end{array}$ & $\begin{array}{l}\text { Council personnel, non-vaccinated } \\
\text { support personnel, someone who has } \\
\text { had some training in this field in their } \\
\text { work or volunteer role, someone who } \\
\text { is responsible for the site i.e. knows } \\
\text { the location very well including any } \\
\text { hazards. }\end{array}$ \\
\hline Human first aid & $\begin{array}{l}\text { Safety officer could be site coordinator / } \\
\text { induction person -would be best if safety } \\
\text { officer and human first aid were together }\end{array}$ & $\begin{array}{l}\text { A trained and current first aider } \\
\text { See page } 24\end{array}$ \\
\hline $\begin{array}{l}\text { Induction / } \\
\text { scribe / data } \\
\text { recorder }\end{array}$ & $\begin{array}{l}\text { Can be non-vaccinated - need pre- } \\
\text { prepared sheet of everything that needs to } \\
\text { be recorded at a site - i.e.; time of arrival - } \\
\text { temperatures; names and contact details } \\
\text { of all people attending and vaccination } \\
\text { status; ensure everyone wearing correct } \\
\text { PPE and taking adequate rests / rotations }\end{array}$ & $\begin{array}{l}\text { Support personnel - i.e. can be non- } \\
\text { vaccinated } \\
\text { See page } 23\end{array}$ \\
\hline
\end{tabular}

Flying-fox Disaster Response Guidelines SEQ 2018. 


\begin{tabular}{|c|c|c|}
\hline & $\begin{array}{l}\text { Ensure that all bats taken into triage are } \\
\text { tagged and recorded }\end{array}$ & \\
\hline Rescue & Local Group /rescuers / carers & $\begin{array}{l}\text { Anyone who is vaccinated and is } \\
\text { trained in flying fox rescue } \\
\text { See page } 24 \& 25\end{array}$ \\
\hline Spraying & Local Group /rescuers / carers & $\begin{array}{l}\text { Anyone who is vaccinated and has had } \\
\text { some training in is spraying flying } \\
\text { foxes } \\
\text { See page } 24 \& 25\end{array}$ \\
\hline $\begin{array}{l}\text { Triage and post } \\
\text { triage } \\
\text { monitoring }\end{array}$ & Local Group /rescuers / carers & $\begin{array}{l}\text { Anyone who is vaccinated and is } \\
\text { trained in flying fox caring, Vets and } \\
\text { Vet nurses } \\
\text { Ideally, they should focus solely on } \\
\text { triage and stabilisation. } \\
\text { See page } 25\end{array}$ \\
\hline $\begin{array}{l}\text { Euthanasia / } \\
\text { drug licence }\end{array}$ & A Vet or Licenced Trauma Carer & $\begin{array}{l}\text { Anyone who holds a valid drug permit } \\
\text { from QLD health and has had some } \\
\text { training in euthanising flying foxes }\end{array}$ \\
\hline Drivers & Local Group /rescuers / carers & $\begin{array}{l}\text { Rescuer/Support personal vaccinated } \\
\text { unless the bats are in } 100 \% \text { secure } \\
\text { containers for transport } \\
\text { See page } 24\end{array}$ \\
\hline $\begin{array}{l}\text { Carers on } \\
\text { standby / } \\
\text { sitters }\end{array}$ & Local or other groups/rescuers/carers & $\begin{array}{l}\text { Anyone who is vaccinated and is } \\
\text { trained in flying fox caring, Vets and } \\
\text { Vet nurses } \\
\text { See page } 24\end{array}$ \\
\hline $\begin{array}{l}\text { Food, water } \\
\text { provision }\end{array}$ & $\begin{array}{l}\text { Local Group /rescuers / carers and Local } \\
\text { Gov }\end{array}$ & Support personnel \\
\hline Body removal & $\begin{array}{l}\text { Local Group /rescuers / carers working } \\
\text { with Local Gov }\end{array}$ & $\begin{array}{l}\text { Anyone who is vaccinated and is } \\
\text { trained in flying fox rescue } \\
\text { See page } 25\end{array}$ \\
\hline
\end{tabular}

\section{NOTES:}

- Ensure where possible that the camp has been divided in quadrants with thumb tags supplied with colours corresponding to quadrants that flying-foxes were taken from - these numbers are the transferred to any paperwork and stay with the flying-fox throughout any care / veterinary treatment.

- Also need to ensure that the site coordinator / inductor assigns rescuers / sprayers to a quadrant so that any bats can be identified if any human/bat contact incident occurs.

Flying-fox Disaster Response Guidelines SEQ 2018. 


\section{DETAILED ROLE DELINIATION}

\section{ROLE - SITE INDUCTOR / INCIDENT CONTROLLER/SCRIBE-}

- Should be one incident controller, 1 scribe and 1 site inductor. Can be non-vaccinated volunteers to inform members of the public what is happening and to keep them out of the working site.

- Set up clear and very visible barriers to the working site with standardised signage indicating that a heat event is taking place and only trained personnel are to pass the barriers. If this is a public area, a small through-way furthest from the site will need to be granted and fenced off.

- Ideally divide colony up quadrants and assign rescuers / sprayers to set quadrants.

- $\quad$ Standardised leaflet drop goes to neighbouring properties.

- All people on site to sign in with induction officer including contact details / emergency contact person (next of kin), vaccination status and role at the site. Refer Attachment 14.4 for volunteer sign-in / recording sheet.

- Ensure (and mark off) that everyone has the correct PPE for their role on site - i.e.; hat, gauntlets, nitrile gloves, long sleeves and pants, gators and sturdy shoes.

- Collate numbers of animals brought in for triage including sex/ age / species.

- Record approximate numbers of deaths at the site and deaths during triage, recovery or transport/ bats taken into triage and id numbers / bats that go to veterinary care and where they were taken.

- Get tag colours and ID numbers of bats, prior to being taken into care and where in the colony that bat was taken from.

- $\quad$ Record the temps and interventions of the rescuers, as well as timing and duration of sprays and responses of the bats.

- $\quad$ Record number going to veterinary care and identification.

- Important to record responses to sprays - positive or negative for future response tailoring.

- Recruit volunteers to record details of bats coming into triage, vital signs and treatment given prior to going to veterinary care - ensure that all bats coming into triage have some form of ID tag.

- Record any human first aid incidences and follow-up that appropriate action has been taken.

- Ensure that when volunteers/carers leave the site they sign-off.

\section{ROLE - COORDINATION / COMMUNICATION}

- Can be non-vaccinated person looking at bat forecaster and Facebook site, coordinating teams of people to respond to camps with highest need.

- Support personnel.

- Council Liaison

ROLE - TRIAGE AREA SET UP AND PACK UP

- Can be non-vaccinated people

- Support personnel

ROLE - FOOD AND WATER PROVISION

- Also can be non-vaccinated volunteers - important that adequate water and food is at each site as each person responding will need a minimum of 3-4 litres available depending on time spent at the site.

\section{ROLE - CARERS ON STANDBY}

- Ability to triage and rescue flying-foxes will be limited by how any vaccinated carers are available to take on heat-affected bats post veterinary assessment.

- Need to have an idea of capacity and availability of carers able to take on adults as well as juveniles affected in a heat response.

Flying-fox Disaster Response Guidelines SEQ 2018. 


\section{ROLE - SAFETY OFFICER / HUMAN FIRST AID OFFICER}

- Full first aid kit / ideally first aid certificate.

- Water for all participants -Large water containers for backpack water containers - (Camelbak etc.).

- Ice vests.

- Ensure that people are rotating out of the heat into shaded areas. Pull out anyone not coping or becoming faint and unwell etc.

- $\quad$ Record the time that each rescuer started working and when they finished.

- Ensure that each rescuer is wearing the appropriate PPE for their task.

- Record any injuries sustained.

- Record any scratches/ bites and identify quadrant that bat came from in addition to the specific bat involved.

- Record each person entering the response site, including their contact details, emergency contact person (Next of Kin), vaccination status and roles.

- Mark off that they have been given the appropriate level of PPE for their role.

- Record any human health incidents., and sign personnel out when leaving.

\section{Refer to Appendix 14.4 for Volunteer sign-in and 14.3 Recording sheet.}

\section{ROLE - COLONY MONITORS}

- Ideally people who know the colonies well, know bat behaviours well or have been trained in camp site event monitoring.

- Monitor the colony leading up to and during the heat event.

- Advise Rescue Personnel and Sprayers of need to intervene and timing of any spraying interventions.

- Also monitoring groups of bats that have been sprayed and the response to spraying, to determine need for removing-flying-foxes for triage, euthanasia or positive response to spraying.

- Monitoring post event for orphaned juveniles.

\section{ROLE - RESCUE AND SPRAYERS}

- If numbers permit, send Rescuers and Sprayers to known quadrant areas identified within the camp, so that all bats that are returned from those volunteers can be identified with a thumb tag as to which location in the camp the bat came from.

- When advised by Colony monitors, Rescuers and Sprayers will remove those animals in need of euthanasia or immediate triage.

- When advised by the Colony monitors, Rescuers will ascertain if bats will tolerate spraying. This needs to be very carefully monitored as any additional stress at this time could cause lifting, with stress leading to possible death. If tolerated, lightly increase the intensity of water and ensure that bats are sprayed directly to effectively saturate them. Once achieved, give an interval of 15 minutes, observe and reattempt spraying again up to 3 times, if tolerated. Success is measured by bats moving back up into the mid-storey.

- Advise Monitors and Site induction personnel which bats, from which quadrants of the camp, have been sprayed, when ,for how long and how many times they have been sprayed.

- Discontinue if bats are showing ANY signs of stress and/or trying to move away.

- Ideally place thumb tag indicating the quadrant of which colony the bat is from. The thumb tag information identifies the bat for further treatment and to ease tracking if any human exposure issues or bat related quarantine issues. This also allows tracking of treatment and responses of bats, to improve feedback and data that we have on our responses. 


\section{ROLE - TRIAGE PERSONNEL}

- Ideally need at least one (1) person licenced in wildlife euthanasia and sedation practice by QLD Health.

- Triage and initial stabilisation of flying-foxes delivered from camp by rescuers.

- Triage and stabilisation of orphans.

- Preparation of flying-foxes for transport to veterinary care

ROLE - BODY REMOVAL

- Any animals euthanased via Lethe barb will need to be separately placed in body bags, and not left onsite.

- Otherwise Council usually carries out mass body removal at some sites. Need to liaise with roost site landholder.

Flying-fox Disaster Response Guidelines SEQ 2018. 


\subsection{RESPONSE EQUIPMENT AND SETUP}

\section{OPERATION SET-UP}

Ideally separate the site into zones required for response operations on-site, namely:

- Site controller/ sit induction point / scribe

- Triage area

- Flying-fox stabilisation and recovery

- Rescue supplies and rest areas including sprayer refill sites

- First Aid areas

- Transport preparation area

Set up clear barriers to demarcate zones, including:

- Cool zones where non-vaccinated people can be present

- Clear hot zones where strictly only vaccinated people can be present

Ensure:

- Clear signage and barriers are erected to keep members of the public safe.

- Have jobs handy such as water collection, food provision etc. for concerned members of the public to feel included without impeding progress.

- Ensure that clear evacuation / exit points are defined in the case of bushfire.

\section{PPE FOR PARTICULAR ROLES}

\section{TRIAGE}

- Triage - gauntlets

- Niltrile gloves

\section{RESCUE}

- Long pants

- Gators

- Enclosed sturdy shoes

- Long-sleeved shirt

- Hat etc

- Nitrile gloves with or without thick leather gloves and gauntlets

- Water - minimum 3L per rotation

\section{TRANSPORT}

- None required once animals in enclosures

All non-flying-fox contact roles, and roles not requiring entry into bush do not require specific PPE. However usual sun protection is recommended as well as personal water. 


\section{SITE SETUP EQUIPMENT}

The following list of equipment is recommended for Response Operations:

- Laminated list of all equipment in relevant containers with checklist for lost/broken/used items

- Community information flyers

- Standardised protocols and role outlines

- AM/FM Radio - Emergency updates

- Map of camps and mud map of triage and rescue site locations including possible evacuation points

- Traffic / barricading material to keep unvacc / MOP out

- F10 hand wash

- Back pack sprayers with extension nozzles

- Saw

- Multi-tools - (e.g. gerber)

- Human first aid kits - including snake bite bandages

- ID tags

- Hats or wrist bands to indicate roles in camp

- iPhone / cameras for recording bat behaviour

- Water containers (human drinking)

- Backpack water carriers (human drinking) - ? camelbak or similar

- Water (spraying bats)

- Ice vests for people

- Shade structures

- Foldable chairs

- Trestle tables - induction site, rest sites, first aid

- Clip boards / iPad if available for data recording

- Head lamps

- Bat thumb tags

- Pens / pencils and masking tape for labels

- PPE - nitrile gloves, gauntlets, gators, sturdy shoes, Face masks

- Personal care pack (personal meds; headache tablets; snacks; specific dietary requirements)

- Check list to record equipment needing replacing for further responses

- List of local amenities, service stations, Council contact.

\section{TRIAGE ZONE SET-UP}

\section{TRIAGE EQUIPMENT}

\section{GENERAL ITEMS}

- Standardised protocols and role outlines

- Esky and ice

- Battery operated fans - at least 9 per site

- Trestle tables - 3 - initial triage, fluid table and third for post fluids monitoring.

- Good lighting - halogen lamps

- Spray bottles and tepid water

- Cages - open wire for increased circulation

- Towels - large and small

- Thermometers

- Body bags

- Water - camel backs for people or adequate cool water

- Ice vests - people

- PPE - gauntlets; nitrile gloves, hats, gators- sturdy shoes and long-sleeved shirts and pants

Flying-fox Disaster Response Guidelines SEQ 2018. 
- Shade structures

- Hand washing stations (tubs)

- Cages- transport and holding

- Head lamps

- Body bags

- Check list to record equipment needing replacing for further responses

\section{CONSUMABLES}

- Syringes various sizes $-1 \mathrm{ml}$ (50 minimum), $3 \mathrm{ml}$ (50 minimum) $10 \mathrm{ml}$ (50 minimum), $20 \mathrm{ml}-(50$ minimum) $60 \mathrm{ml}-(50$ minimum $)$

- Needles - 25G; 23G; 18 G- 1 inch (100 each minimum)

- $2.5 \%$ glucose saline fluid bags $500 \mathrm{ml}$ bags -2 minimum - (need to be refrigerated after first use)

- Hartmann's fluid bags $1 \mathrm{~L}-4$ minimum

- F10 hand wash

- Vet wrap - 2 x $5 \mathrm{~cm}$ diameter rolls per response

- Tubigrib - medium $1 \times$ roll

- Fixomul tape - 1 roll

- Self-warming hot packs - pack 50

- Gauze swabs - pack 50-100

- Alcohol swabs (not for cooling) - 1 tub per table - alcohol in cotton balls)

\section{MEDICAL EQUIPMENT}

- Stethoscope

- Pulse oximeter (if funding allows)

\section{MEDICATIONS}

- Trauma carer drug permits - (only if personnel with valid and current permit are present) pamlin; lethebarb; alfaxan; fluids (must go in lockable safe below)

- Lockable portable safe

- Betadine

- Flamazine ointment

- False tears / lacrilube

- Glucodin powder

\section{IMPORTANT NOTE:}

Attempt to avoid Hi Vis vests for identification of people dealing with bats to avoid distressing bats. Investigate alternate options - coloured hats, wrist or arm bands. However, this may not be optional as some sites and land managers require High Vis vests when undertaking work on reserves or other locations as part of their WH\&S policies. Check with your local council.

Flying-fox Disaster Response Guidelines SEQ 2018. 


\subsection{TRIAGE PROTOCOL}

Ideally at least one (1) person licenced in wildlife euthanasia and sedation practice by QLD Health should be present during response operations.

Bats that have responded to three (3) sprays and have shown great improvement in demeanour but not $100 \%$ give 10\% SC fluids - (50:50 2.5\% Glucose/saline and Hartmann's).

NO bat brought in from a heat event should receive hydration via oral fluids.

- All bats that have been brought in from a heat event, that have not been returned to the camp, up the tree, require veterinary examination, as they will have organ damage due to heat stroke.

- Brighter bats that have responded to spraying and have a stable rectal temperature after spraying, can be kept in care for $48 \mathrm{hrs}$ and then returned to wild or released if no veterinary facilities are available.

\section{TRIAGE - ALL BATS THAT REQUIRED MOVING FROM CAMP FOR TRIAGE}

- Bats not responding to spraying or that appear to be deteriorating despite spraying, or are not responsive at all during spraying, need to come in for triage / veterinary treatment.

- Those with obvious injuries and seizuring animals need to come in for triage / veterinary treatment.

- Need to use judgement as to whether you remove the seizuring animal or non-responsive / injured animal at the risk of not being able to spray a large group and/or disturbing them. Remember any additional stress at this point could mean death for all of the bats in a group.

- Ideally give any responsive Bat Pamlin @ $0.5 \mathrm{mg} / \mathrm{kg}$ IM if licenced to do so. This helps with myopathy and reduced anxiety of handling and further increasing of body temperature.

- Any seizuring animal give $1 \mathrm{mg} / \mathrm{kg}$ IM or per rectum (Pamlin will absorb per rectum even in shocky bats and may be safer than giving an injection to a seizuring animal)

- Glucose should be administered orally (either a glucodin powder paste or less than $1 \mathrm{ml}$ of concentrated liquid; or on gums as well as in SC or IV fluids. Glucose will cross the mucous membrane into the blood stream even in quite shocky bats.

- Monitor rectal temperature initially and then every minute until the rectal temperature drops below $40^{\circ} \mathrm{C}$ - stop sprays with tepid water and fanning at $40^{\circ} \mathrm{C}$.

- Continue to monitor rectal temperature every 2-5 minutes after this time, as shock can cause the temperature to drop rapidly going into hypothermia as shock worsens.

- $\quad$ Place False Tears in all bat eyes (gel is best).

- Note any bat that may have regurgitated (for veterinary attention) during rescue or triage.

- Leave non-euthanased dead mums in place for a few days where possible, as this often aids rescue of orphaned young who may come down from the tree.

- Bats can go into transport cages once rectal temperature and temperament has been stable at $37-38{ }^{\circ} \mathrm{C}$ and Oral Mucous Membrane Capillary Refill Time (OMMCRT) has been around 2-3 seconds or less for 10 minutes - continue to monitor these animals for regression every 10 minutes

- If seizuring recurs in these animals or temperature drops again below normal and not responding to repeating treatment - euthanasia required.

- IF AT ALL POSSIBLE: ALL BATS THAT ARE BROUGHT IN FOR TRIAGE, SHOULD BE SEEN BY A VETERINARIAN AS THEY WILL ALL BE SUFFERING SOME DEGREE OF ORGAN DAMAGE CAUSED BY HEAT STROKE, REQUIRING MONITORING AND TREATMENT

Flying-fox Disaster Response Guidelines SEQ 2018. 


\section{TRIAGE - BATS REQUIRING IMMEDIATE EUTHANASIA}

- Seizuring not controlled after Pamlin, glucose and/or cooling.

- Severe respiratory distress.

- Initial rectal temperatures of $>41.5^{\circ} \mathrm{C}$.

- Blind / non-responsive animals.

- Animals with concurrent injuries - e.g.; fractures, severe lacerations etc.

- Animals whose rectal temperatures drop below $35^{\circ} \mathrm{C}$ and have Oral Mucous Membrane Capillary Refill Time (OMMCRT) of greater than $>3$ seconds and won't respond to SC fluids and warming

\section{TRIAGE - ORPHANS}

- Orphaned bats in a heat event may not be immediately apparent.

- Searching the camp for weak, emaciated juveniles in the days post heat event will identify those needing to be brought into care.

- Some will come down to dead mothers left on the ground up to 2-3 days after the event.

- Care must be taken not to remove healthy juveniles whose mothers may return.

- When observing the camp for orphaned young, ensure that any activity within the camp is stopped by 5.30 pm so that normally crèched juveniles are not mistaken for orphaned young.

- Orphans of a heat event will need specialised care.

- Orphaned young during heat events will also be suffering from a degree of heat stroke and resultant organ damage.

- All orphaned young in a heat event should be seen by a wildlife veterinarian in order to determine if treatment for aspiration pneumonia and adequate fluid therapy with or without gut protectant treatment is started if required.

- Aspiration pneumonia is extremely common in orphaned flying-foxes in heat stroke, as they will often be hypoglycaemic and their GI tracts are often damaged by heat and will not be absorbing nutrients and fluids normally.

- This means that their body condition and development needs to be closely monitored, as their ability to absorb nutrients from formula in care, will not be the same as normal orphaned flying-foxes.

- Fluid therapy is vitally important for at least the first week post heat event and oral feeds should not be started until orphans have been rehydrated adequately and supplemented with glucose.

- An initial feed of glucodin should be attempted - (not more than $2 \mathrm{ml}$ ) and the amount given orally should increase gradually in order to avoid aspiration and resultant pneumonia.

- Feeds need to be increased conservatively as the GI (Gastro intestinal) tract will also have compromised ability to digest and absorb due to damage.

\section{CORRECT TRANSPORT PROCEDURE}

- Open wire cages to allow good air flow.

- Ensure that each box is positioned to allow air flow to reach all bats in transport.

- Ensure that transport has air-conditioning with or without adequate air flow to reach the wildlife hospital or carer.

- Ensure that the wildlife hospital or carer groups are aware that flying-fox patients from the heat event will require their attention and will be transported to them, so they are aware and prepared for their arrival.

- DO NOT wrap flying-foxes in transport cages. This will prevent further radiated or evaporative cooling even if the towels are wet and will continue to increase the temperature of the flying-foxes.

- DO NOT offer flying-foxes oral fluids post heat event rescue - they are at risk of aspirating.

- Ensure that all cages are secure to prevent accidental opening or excessive movement during transport. 


\subsection{AFTER THE EVENT - MANAGING FLYING- FOXES POST HSE}

Ideally all flying-foxes that have survived a heat event and need to come in to care should see a wildlife veterinarian

All flying-foxes that survive a heat event should be held in care for at least 6 weeks, as the full extent of damage due to heat stroke may not be immediately apparent and significant recovery and rehabilitation will be required to overcome the myopathy and organ damage due to heat stroke.

\section{All flying-foxes will have some degree of:}

\section{Gastro Intestinal Tract Damage}

- This can range from full gut lining sloughing to a reduced ability to digest and absorb nutrients.

- Depending on the degree of damage, intensive antibiotic and gut protectant treatment with or without

- fluid therapy may be needed.

- All bats should be placed on gut protectants post HSE such as Carafate in smoothies.

- All bats will require nutritional supplementation with high protein diets.

\section{Renal/Kidney Damage}

- This can be direct from heat damage to indirect from severe dehydration.

- Fluid therapy is vitally important especially in the first 48 hours and up to at least the first week post HSE.

- Oral intake of volumes greater than $2 \mathrm{ml}$ should not be attempted until rehydration and glucose supplementation has occurred and the flying-fox is showing signs of improved hydration, a OMMCRT of two (2) seconds or less and is strong enough to hang unassisted and is moving and grooming normally.

\section{Damage to the Thalamus}

- Some flying-foxes surviving the initial insults of an HSE may have permanent damage to the thalamus, the temperature regulating centre of the brain, making them more prone to succumbing in future events.

- Surviving flying-foxes (mainly adults) need to be monitored closely whilst in care, to ensure that they can thermoregulate normally prior to release.

\section{Myopathy}

- This can be exertional due to prolonged fanning to attempt cooling (often for several days leading into a heat event) or non-exertional from direct damage due to heat.

- Myopathy may be initially apparent as severe stiffness and reluctance to extend wings, move around or invert to defaecate and urinate.

- Myopathy can also be subtle and become apparent weeks into care, with muscle wasting occurring to a greater degree than expected from a normal bat in care.

- Myopathy can result in scarring or fibrosis of muscle tissue and if severe, can result in a flying-fox being unreleasable as muscle fibre damage and scarring may be too severe for regeneration to occur during the rehabilitation phase. 


\section{Vascular Bed Damage}

- This is usually seen in flying-foxes as damage to the wing membranes.

- If flying-foxes survive the initial insult to vascular beds, damage to vascular beds throughout the body can become apparent as wing-sloughing or inflammation of the membranes and can be mistaken for slimy wing.

- This can occur up to 6 weeks post HSE and needs to be treated aggressively to avoid membrane scarring and contraction

\section{MANAGING FLYING-FOXES POST HSE}

\section{Initial considerations}

- Due to their high basal metabolic rates, flying-foxes are usually hypoglycaemic post HSE.

- This leads to weakness and disorientation combined with direct damage to the brain due to excessively high body temperature.

- The GI tract will also have a poor blood supply due to dehydration and shock and direct damage. Anything given orally will sit in the GI tract and regurgitation and resultant aspiration is a common and often life-threatening sequelae needing immediate and aggressive treatment.

- Hence, SC or IV fluid therapy is vital in the initial management of flying-foxes post HSE.

- ALL FLYING-FOXES SHOULD BE GIVEN NO ORAL FLUIDS other than small (up to $1 \mathrm{ml}$ of $50 \%$ glucose or ideally glucodin paste on oral mucous membranes), until adequate hydration has been achieved and the flying-fox is strong enough to hang and move normally and is bright.

- Even then, oral supplantation needs to be started with small volumes gradually increasing intake as tolerated.

\section{Nutritional Supplementation}

- High protein smoothies with gut protectants such as carafate should be given to all flying-foxes in care post HSE to offset losses due to GI tract and renal compromise.

- Even so, supplementation needs to be started conservatively and gradually increased whilst monitoring body condition and hydration closely.

\section{REHABILITATION}

- Adult flying-foxes taken into care during a HSE should be kept for a minimum of 6 weeks.

- Once complications have been overcome, all flying-foxes need adequate time in large flight aviaries to ensure that they are capable of increasing their fitness, strength and range of motion required for flight in the wild.

- Their ability to maintain their hydration and body condition during this time needs to be monitored closely to ensure that they will be capable of returning to the wild successfully. 


\subsection{HSE REPORTING}

Data has the capacity to better frame our responses to HSE's as well as to provide valuable information on the effect of HSE's on the flying-fox population as a whole.

Event Data (Refer Appendix 14.2 \& 14.3) should be entered on the Flying Fox heat stress forecaster, within which a data entry form exists. https://www.animalecologylab.org/ff-heat-stress-forecaster.html

Reporting should also occur to the relevant Regional Council and EHP via the incident or site coordinator.

- Data can be collected by having a hot debrief (immediately after the event) and then at a cold debrief later (after the event giving a good overall picture) - ensure that data collected is entered into heat stress forecaster data, but also retain a copy of any data for use locally in future responses. We need to ensure the ability to track bats post HSE treatment and care, to assess future success of bats affected that survive.

- Keep a record of lessons learnt and modifications required for future responses related to each site. 


\subsection{BIBLIOGRAPHY}

Gfeller, G 2005, 'Heatstroke', in Ettinger, SJ \& Feldman, EC, Textbook of Veterinary Internal Medicine, 6th edn, St Louis, Missouri. [ichẹ]

Snoyman, S, Jasmina, M, Brown,C 2012, 'Nursing females are more prone to heats stress: Demography matters when managing flying -foxes for climate change', Applied Animal Behaviour isepes Science, vol 142 pp. 90-97.

Welbergen, 2012 ISBN: 978-84-87790-69-0

Https://www.flickr.com/photos/sandyfernee/2366877935

https://www.logan.qld.gov.au/ data/assets/pdf file/0013/333031/DEHP Living-near-flying-foxes-factsheet.pdf

https://www.worksafe.qld.gov.au/ data/assets/pdf file/0003/82902/lyssavirus-handling-bats.pdf 
Flying-fox Disaster Response Plan 2018

\subsection{APPENDICES}

\subsection{SEQ HSE CAMP STRATEGIES - GATHERED AT HSE WORKSHOP}

\section{SUBREGIONAL RESPONSES}

\section{HSE Prone Camps, Appropriate Response Action}

- Which camps have historically had HSE and which NEW camps may be of concern?

- Based on the individual characteristics of each camp - i.e. demeanour of bats; accessibility; local resources; camp structure and vegetation, what are appropriate intervention methods for managing heat stress?

i.e.; water truck/ute sprayers; shade provision; backpack spraying; no intervention until late stages, as bats are too unaccustomed to human presence?

\begin{tabular}{|c|c|c|c|c|c|c|c|c|c|c|}
\hline \multicolumn{11}{|c|}{ GYMPIE REGIONAL COUNCIL } \\
\hline Camp & $\begin{array}{l}\text { Tenure / Land } \\
\text { Manager - } \\
\text { Contact } \\
\text { Details }\end{array}$ & $\begin{array}{l}\text { Existing planning } \\
\text { and response } \\
\text { documents }\end{array}$ & $\begin{array}{l}\text { Appropriate } \\
\text { Response Action }\end{array}$ & Access & $\begin{array}{l}\text { Site Response } \\
\text { Coordination }\end{array}$ & $\begin{array}{l}\text { Principle Carer } \\
\text { Groups - First } \\
\text { Responders }\end{array}$ & $\begin{array}{l}\text { Resources } \\
\text { Available and } \\
\text { Contact Details }\end{array}$ & Site Issues & $\begin{array}{l}\text { Monitoring } \\
\text { Activities }\end{array}$ & $\begin{array}{l}\text { Alternate } \\
\text { Remediation } \\
\text { Action }\end{array}$ \\
\hline $\begin{array}{l}\text { Widgee } \\
\text { Crossing }\end{array}$ & $\begin{array}{l}\text { Gympie } \\
\text { Council } \\
\text { Sewage } \\
\text { Treatment Plant } \\
\text { and Waterway }\end{array}$ & Nil & $\begin{array}{l}\text { No Intervention } \\
\text { during Event - } \\
\text { Very stressy camp. }\end{array}$ & $\begin{array}{l}\text { Good Street } \\
\text { Access } \\
\text { Difficult } \\
\text { access } \\
\text { (creek line) } \\
\text { for large } \\
\text { part of site. }\end{array}$ & $\begin{array}{l}\text { Rachel Lyons } \\
\text { (WIldcare) }\end{array}$ & $\begin{array}{l}\text { Wildcare } \\
\text { Annara } \\
\text { RSPCA - } \\
\text { Eumundi } \\
\text { Bat Rescue } \\
\text { Sunshine Coast }\end{array}$ & $\begin{array}{l}\text { Rescue } \\
\text { Equipment - } \\
\text { Wildcare } \\
\text { Basic Triage } \\
\text { Equipment } \\
\text { Wildcare Trauma } \\
\text { Carer - Rachel } \\
\text { Lyons } \\
\text { Veterinary } \\
\text { Support - } \\
\text { RSPCA Eumundi } \\
\text { \& Australia Zoo } \\
\text { Wildlife Hospital }\end{array}$ & $\begin{array}{l}\text { Difficult access } \\
\text { (creek line) for } \\
\text { large part of } \\
\text { site, LRFF } \\
\text { camp in } \\
\text { summer, Very } \\
\text { Weedy, Very } \\
\text { flighty camp, } \\
\text { WH\&S issues } \\
\text { (terrain, water, } \\
\text { dense } \\
\text { vegetation), } \\
\text { Maternity site } \\
\text { GHFF \& BFF. }\end{array}$ & $\begin{array}{l}\text { Afternoon } \\
\text { monitoring } \\
\text { organised by } \\
\text { Rachel Lyons on } \\
\text { susceptible days. } \\
\text { EHP } 3 \text { monthly } \\
\text { monitoring. }\end{array}$ & $\begin{array}{l}\text { Ongoing Cats Claw } \\
\text { Creeper Vine } \\
\text { Management (Bio } \\
\text { control and } \\
\text { Manual), Improve } \\
\text { Buffering of Roost } \\
\text { through vegetation } \\
\text { plantings. Careful } \\
\text { weed replacement } \\
\text { over time. Difficult } \\
\text { rehab site - very } \\
\text { expensive project. }\end{array}$ \\
\hline Kandanga & $\begin{array}{l}\text { Private } \\
\text { Property - } \\
\text { Contact via } \\
\text { Terri Ridgeway } \\
\text { \& Rachel } \\
\text { Lyons }\end{array}$ & Nil & $\begin{array}{l}\text { No Intervention } \\
\text { during Event - } \\
\text { Very stressy camp. }\end{array}$ & $\begin{array}{l}\text { Via Private } \\
\text { Property } \\
\text { Access- } \\
\text { difficult } \\
\text { access }\end{array}$ & $\begin{array}{l}\text { Terri Ridgeway (Bat } \\
\text { Rescue) }\end{array}$ & $\begin{array}{l}\text { Bat Rescue } \\
\text { Sunshine Coast } \\
\text { Wildcare } \\
\text { Annara } \\
\text { RSPCA - } \\
\text { Eumundi }\end{array}$ & $\begin{array}{l}\text { Rescue } \\
\text { Equipment - } \\
\text { Wildcare } \\
\text { Basic Triage } \\
\text { Equipment }\end{array}$ & $\begin{array}{l}\text { Access requires } \\
\text { notification of } \\
\text { landholder and } \\
\text { tenants. Large } \\
\text { GHFF } \\
\text { maternity site. }\end{array}$ & $\begin{array}{l}\text { Landholder when } \\
\text { asked. }\end{array}$ & Not known \\
\hline
\end{tabular}


Flying-fox Disaster Response Plan 2018

\begin{tabular}{|c|c|c|c|c|c|c|c|c|c|c|}
\hline & & & & & & & $\begin{array}{l}\text { Wildcare Trauma } \\
\text { Carer - Rachel } \\
\text { Lyons } \\
\text { Veterinary } \\
\text { Support- } \\
\text { RSPCA Eumundi } \\
\text { \& Australia Zoo } \\
\text { Wildlife Hospital } \\
\end{array}$ & & & \\
\hline \multicolumn{11}{|c|}{ SUNSHINE COAST REGIONAL COUNCIL } \\
\hline Camp & $\begin{array}{l}\text { Tenure / } \\
\text { Land } \\
\text { Manager - } \\
\text { Contact } \\
\text { Details }\end{array}$ & $\begin{array}{l}\text { Existing planning } \\
\text { and response } \\
\text { documents }\end{array}$ & $\begin{array}{l}\text { Appropriate } \\
\text { Response Action }\end{array}$ & Access & $\begin{array}{l}\text { Site Response } \\
\text { Coordination }\end{array}$ & $\begin{array}{l}\text { Principle Carer } \\
\text { Groups - First } \\
\text { Responders }\end{array}$ & $\begin{array}{l}\text { Resources } \\
\text { Available and } \\
\text { Contact Details }\end{array}$ & Site Issues & $\begin{array}{l}\text { Monitoring } \\
\text { Activities }\end{array}$ & $\begin{array}{l}\text { Alternate } \\
\text { Remediation } \\
\text { Action }\end{array}$ \\
\hline $\begin{array}{l}\text { Palmwoods - } \\
\text { Jubilee Drive }\end{array}$ & DTMR & Nil & $\begin{array}{l}\text { Potential Spray } \\
\text { Intervention } \\
\text { during Event if } \\
\text { FF's allow }\end{array}$ & Via DTMR & $\begin{array}{l}\text { Claire Smith } \\
\text { (Sunshine Coast } \\
\text { Wildlife Rescue / } \\
\text { Bat Rescue } \\
\text { Sunshine Coast } \\
\text { (Carmel Givens) }\end{array}$ & $\begin{array}{l}\text { Sunshine Coast } \\
\text { Wildlife Rescue, } \\
\text { Bat Rescue } \\
\text { Sunshine Coast }\end{array}$ & $\begin{array}{l}\text { Rescue } \\
\text { Equipment - } \\
\text { Wildcare } \\
\text { Basic Triage } \\
\text { Equipment } \\
\text { Veterinary } \\
\text { Support- } \\
\text { Australia Zoo } \\
\text { Wildlife Hospital }\end{array}$ & & $\begin{array}{l}\text { HSE monitoring } \\
\text { organised by } \\
\text { Wildlife Rescue } \\
\text { Sunshine Coast } \\
\text { on susceptible } \\
\text { days. } \\
\text { SCC } 3 \text { monthly } \\
\text { monitoring. }\end{array}$ & $\begin{array}{l}\text { Mid-storey } \\
\text { Vegetation } \\
\text { Management }\end{array}$ \\
\hline Landsborough & $\begin{array}{l}\text { Council } \\
\text { Reserve }\end{array}$ & Nil & $\begin{array}{l}\text { Potential Spray } \\
\text { Intervention } \\
\text { during Event if } \\
\text { FF's allow }\end{array}$ & & $\begin{array}{l}\text { (Carmel Givens) } \\
\text { Bat Rescue } \\
\text { Sunshine Coast }\end{array}$ & $\begin{array}{l}\text { Bat Rescue } \\
\text { Sunshine Coast, } \\
\text { BCRQ }\end{array}$ & $\begin{array}{l}\text { Rescue } \\
\text { Equipment-- } \\
\text { BRSC } \\
\text { Basic Triage } \\
\text { Equipment } \\
\text { Veterinary } \\
\text { Support- } \\
\text { Australia Zoo } \\
\text { Wildlife Hospital }\end{array}$ & & $\begin{array}{l}\text { HSE monitoring } \\
\text { organised by } \\
\text { Carmel Givens } \\
\text { on susceptible } \\
\text { days. } \\
\text { Bat Rescue } \\
\text { Sunshine Coast } \\
\text { SCC } 3 \text { monthly } \\
\text { monitoring. }\end{array}$ & $\begin{array}{l}\text { Ongoing } \\
\text { Vegetation } \\
\text { Management }\end{array}$ \\
\hline $\begin{array}{l}\text { Mary } \\
\text { Cairncross }\end{array}$ & $\begin{array}{l}\text { Council } \\
\text { Reserve }\end{array}$ & Nil & $\begin{array}{l}\text { No Intervention } \\
\text { during Event - } \\
\text { Observe. }\end{array}$ & & $\begin{array}{l}\text { (Carmel Givens) } \\
\text { Bat Rescue } \\
\text { Sunshine Coast }\end{array}$ & $\begin{array}{l}\text { Bat Rescue } \\
\text { Sunshine Coast } \\
\text { BCRQ }\end{array}$ & $\begin{array}{l}\text { Rescue } \\
\text { Equipment - } \\
\text { BRSC } \\
\text { Basic Triage } \\
\text { Equipment } \\
\text { Veterinary } \\
\text { Support- } \\
\text { Australia Zoo } \\
\text { Wildlife Hospital }\end{array}$ & & $\begin{array}{l}\text { HSE monitoring } \\
\text { organised by } \\
\text { Carmel Givens?? } \\
\text { on susceptible } \\
\text { days. } \\
\text { SCC } 3 \text { monthly } \\
\text { monitoring. }\end{array}$ & $?$ \\
\hline
\end{tabular}


Flying-fox Disaster Response Plan 2018

\begin{tabular}{|c|c|c|c|c|c|c|c|c|c|c|}
\hline Camp & $\begin{array}{l}\text { Tenure / } \\
\text { Land } \\
\text { Manager - } \\
\text { Contact } \\
\text { Details } \\
\end{array}$ & $\begin{array}{l}\text { Existing planning } \\
\text { and response } \\
\text { documents }\end{array}$ & $\begin{array}{l}\text { Appropriate } \\
\text { Response Action }\end{array}$ & Access & $\begin{array}{l}\text { Site Response } \\
\text { Coordination }\end{array}$ & $\begin{array}{l}\text { Principle Carer } \\
\text { Groups - First } \\
\text { Responders }\end{array}$ & $\begin{array}{l}\text { Resources } \\
\text { Available and } \\
\text { Contact Details }\end{array}$ & Site Issues & $\begin{array}{l}\text { Monitoring } \\
\text { Activities }\end{array}$ & $\begin{array}{l}\text { Alternate } \\
\text { Remediation } \\
\text { Action }\end{array}$ \\
\hline Caboolture & $\begin{array}{l}\text { Private } \\
\text { Property - } \\
\text { contacted } \\
\text { via door } \\
\text { knock }\end{array}$ & & $\begin{array}{l}\text { No intervention } \\
\text { during event - } \\
\text { large site, multiple } \\
\text { observation sites }\end{array}$ & $\begin{array}{l}\text { Through } \\
\text { private property }\end{array}$ & & $\begin{array}{l}\text { BDWR \& BCRQ } \\
\text { AZWH }\end{array}$ & $\begin{array}{l}\text { Triage area - } \\
\text { driveway of } \\
\text { private property } \\
\text { BDWR Triage } \\
\text { Trailer }\end{array}$ & $\begin{array}{l}\text { No power } \\
\text { No water }\end{array}$ & $\begin{array}{l}\text { Monthly } \\
\text { monitoring by } \\
\text { Council. } \\
\text { HSE - } \\
\text { Volunteers } \\
\text { Margaret } \\
\text { Snowden } \\
\end{array}$ & $\begin{array}{l}\text { Replant } \\
\text { understorey at } \\
\text { Colburn way }\end{array}$ \\
\hline Woodford & $\begin{array}{l}\text { Council } \\
\text { Reserve }\end{array}$ & $\begin{array}{l}\text { Council Response } \\
\text { Plan - Council Sites }\end{array}$ & $\begin{array}{l}\text { No intervention } \\
\text { during event - no } \\
\text { water. Two } \\
\text { locations. }\end{array}$ & 2 access points & Gabi Friebe & $\begin{array}{l}\text { Bat Rescue } \\
\text { Sunshine Coast } \\
\text { AZWH }\end{array}$ & $\begin{array}{l}\text { Triage area - } \\
\text { Webb Lane }\end{array}$ & $\begin{array}{l}\text { No power } \\
\text { No water }\end{array}$ & $\begin{array}{l}\text { Monthly } \\
\text { monitoring by } \\
\text { Council. } \\
\text { HSE - Gabi } \\
\text { Friebe } \\
\end{array}$ & \\
\hline Burpengary & $\begin{array}{l}\text { Council } \\
\text { Reserve }\end{array}$ & $\begin{array}{l}\text { Council Response } \\
\text { Plan - Council Sites }\end{array}$ & $\begin{array}{l}\text { Potential Spray } \\
\text { Intervention }\end{array}$ & Easy Access & Byron Cann & $\begin{array}{l}\text { BDWR } \\
\text { AZWH }\end{array}$ & $\begin{array}{l}\text { BDWR Triage } \\
\text { Trailer }\end{array}$ & $\begin{array}{l}\text { No power } \\
\text { No water }\end{array}$ & $\begin{array}{l}\text { Monthly } \\
\text { monitoring by } \\
\text { Council. } \\
\text { HSE - Gabi } \\
\text { Friebe } \\
\end{array}$ & $\begin{array}{l}\text { Community } \\
\text { education }\end{array}$ \\
\hline Dayboro & $\begin{array}{l}\text { Private } \\
\text { Property - } \\
\text { Chris } \\
\text { Frazer via } \\
\text { Phone }\end{array}$ & & $\begin{array}{l}\text { No intervention } \\
\text { during event }\end{array}$ & & & & & & $\begin{array}{l}\text { Monthly } \\
\text { monitoring by } \\
\text { Council. } \\
\text { HSE- } \\
\text { Landholder? }\end{array}$ & $\begin{array}{l}\text { Community } \\
\text { Education }\end{array}$ \\
\hline \multicolumn{11}{|c|}{ BRISBANE CITY COUNCIL } \\
\hline Camp & $\begin{array}{l}\text { Tenure / } \\
\text { Land } \\
\text { Manager - } \\
\text { Contact } \\
\text { Details } \\
\end{array}$ & $\begin{array}{l}\text { Existing planning } \\
\text { and response } \\
\text { documents }\end{array}$ & $\begin{array}{l}\text { Appropriate } \\
\text { Response Action }\end{array}$ & Access & $\begin{array}{l}\text { Site Response } \\
\text { Coordination }\end{array}$ & $\begin{array}{l}\text { Principle Carer } \\
\text { Groups - First } \\
\text { Responders }\end{array}$ & $\begin{array}{l}\text { Resources } \\
\text { Available and } \\
\text { Contact Details }\end{array}$ & Site Issues & $\begin{array}{l}\text { Monitoring } \\
\text { Activities }\end{array}$ & $\begin{array}{l}\text { Alternate } \\
\text { Remediation } \\
\text { Action }\end{array}$ \\
\hline Mt Ommaney & $\begin{array}{l}\text { Private - } \\
\text { LFW } \\
\text { Property }\end{array}$ & & & $\begin{array}{l}\text { Contact } \\
\text { landholder via } \\
\text { phone / } \\
\text { visitation }\end{array}$ & & & & & & $\begin{array}{l}\text { Manage exotic } \\
\text { groundcovers, } \\
\text { tobacco bush and } \\
\text { devils fig. Canopy } \\
\text { comprises } E \text {. } \\
\text { tereticornis }\end{array}$ \\
\hline $\begin{array}{l}\text { Vileys Scrub } \\
\text { Mt Ommaney }\end{array}$ & $\begin{array}{l}\text { Brisbane } \\
\text { City } \\
\text { Council } \\
\text { Reserve } \\
\end{array}$ & & & $\begin{array}{l}\text { Enter via } \\
\text { Summit Street }\end{array}$ & & & $\begin{array}{l}\text { Water Tank and } \\
\text { Tap onsite. } \\
\text { Picnic Tables and } \\
\text { shelter on Site }\end{array}$ & $\begin{array}{l}\text { Deer also } \\
\text { present on site } \\
\text { - Risk }\end{array}$ & & $\begin{array}{l}\text { Nil - good } \\
\text { vegetation all strata }\end{array}$ \\
\hline $\begin{array}{l}\text { Westlake } \\
\text { Drive }\end{array}$ & $\begin{array}{l}\text { Brisbane } \\
\text { City } \\
\text { Council } \\
\text { Reserve }\end{array}$ & & & $\begin{array}{l}\text { Enter via } \\
\text { Summit Street }\end{array}$ & & & $\begin{array}{l}\text { Water Tank and } \\
\text { Tap onsite. } \\
\text { Picnic Tables and } \\
\text { shelter on Site }\end{array}$ & $\begin{array}{l}\text { Deer also } \\
\text { present on site } \\
\text { - Risk }\end{array}$ & & $\begin{array}{l}\text { Nil - good } \\
\text { vegetation all strata }\end{array}$ \\
\hline $\begin{array}{l}\text { Coopers } \\
\text { Plains }\end{array}$ & & & & & & & & & & \\
\hline
\end{tabular}


Flying-fox Disaster Response Plan 2018

\begin{tabular}{|c|c|c|c|c|c|c|c|c|c|c|}
\hline Parkinson & & & & & & & & & & \\
\hline \multicolumn{11}{|c|}{ LOGAN CITY COUNCIL } \\
\hline Camp & $\begin{array}{l}\text { Tenure / } \\
\text { Land } \\
\text { Manager - } \\
\text { Contact } \\
\text { Details }\end{array}$ & $\begin{array}{l}\text { Existing planning } \\
\text { and response } \\
\text { documents }\end{array}$ & $\begin{array}{l}\text { Appropriate } \\
\text { Response Action }\end{array}$ & Access & $\begin{array}{l}\text { Site Response } \\
\text { Coordination }\end{array}$ & $\begin{array}{l}\text { Principle Carer } \\
\text { Groups - First } \\
\text { Responders }\end{array}$ & $\begin{array}{l}\text { Resources } \\
\text { Available and } \\
\text { Contact Details }\end{array}$ & Site Issues & $\begin{array}{l}\text { Monitoring } \\
\text { Activities }\end{array}$ & $\begin{array}{l}\text { Alternate } \\
\text { Remediation } \\
\text { Action }\end{array}$ \\
\hline Regents Park & $\begin{array}{l}\text { Logan City } \\
\text { Council }\end{array}$ & Nil & $\begin{array}{l}\text { Potential Spray } \\
\text { Intervention } \\
\text { during Event if } \\
\text { FF's allow }\end{array}$ & $\begin{array}{l}\text { Good Street } \\
\text { Access }\end{array}$ & Leanne Robertson & $\begin{array}{l}\text { BCRQ } \\
\text { BQ } \\
\text { ABC }\end{array}$ & $\begin{array}{l}\text { BCRQ - Water } \\
\text { Trailer } \\
\text { BQ - Response } \\
\text { Trailer }\end{array}$ & $\begin{array}{l}\text { Little Shade and } \\
\text { Space for triage } \\
\text { set-up. } \\
\text { No water on } \\
\text { site. }\end{array}$ & Visual & $\begin{array}{l}\text { Improve } \\
\text { Vegetation mid and } \\
\text { lower storey and } \\
\text { gradually phase out } \\
\text { weeds. }\end{array}$ \\
\hline Cedar Grove & $\begin{array}{l}\text { Logan City } \\
\text { Council }\end{array}$ & Nil & $\begin{array}{l}\text { Potential Spray } \\
\text { Intervention } \\
\text { during Event if } \\
\text { FF's allow - } \\
\text { Depends where } \\
\text { bats are located on } \\
\text { site. }\end{array}$ & & Leanne Robertson & $\begin{array}{l}\text { BCRQ } \\
\text { BQ } \\
\text { ABC }\end{array}$ & $\begin{array}{l}\text { BCRQ - Water } \\
\text { Trailer } \\
\text { BQ - Response } \\
\text { Trailer }\end{array}$ & & $\begin{array}{l}\text { Visual via } \\
\text { Council } \\
\text { easements }\end{array}$ & Nil \\
\hline Cedar Vale & $\begin{array}{l}\text { Logan City } \\
\text { Council }\end{array}$ & Nil & $\begin{array}{l}\text { Potential Spray } \\
\text { Intervention } \\
\text { during Event if } \\
\text { FF's allow }\end{array}$ & & Leanne Robertson & & $\begin{array}{l}\text { BCRQ - Water } \\
\text { Trailer } \\
\text { BQ - Response } \\
\text { Trailer } \\
\end{array}$ & $\begin{array}{l}\text { Difficult to } \\
\text { move around } \\
\text { site }\end{array}$ & & Nil \\
\hline \multicolumn{11}{|c|}{ IPSWICH CITY COUNCIL } \\
\hline Camp & $\begin{array}{l}\text { Tenure / } \\
\text { Land } \\
\text { Manager - } \\
\text { Contact } \\
\text { Details } \\
\end{array}$ & $\begin{array}{l}\text { Existing planning } \\
\text { and response } \\
\text { documents }\end{array}$ & $\begin{array}{l}\text { Appropriate } \\
\text { Response Action }\end{array}$ & Access & $\begin{array}{l}\text { Site Response } \\
\text { Coordination }\end{array}$ & $\begin{array}{l}\text { Principle Carer } \\
\text { Groups - First } \\
\text { Responders }\end{array}$ & $\begin{array}{l}\text { Resources } \\
\text { Available and } \\
\text { Contact Details }\end{array}$ & Site Issues & $\begin{array}{l}\text { Monitoring } \\
\text { Activities }\end{array}$ & $\begin{array}{l}\text { Alternate } \\
\text { Remediation } \\
\text { Action }\end{array}$ \\
\hline Yamanto & $\begin{array}{l}\text { Private } \\
\text { Landholder }\end{array}$ & & $\begin{array}{l}\text { Potential Spray } \\
\text { Intervention }\end{array}$ & $\begin{array}{l}\text { Landholder } \\
\text { Permission } \\
\text { required. } \\
\text { Difficult } \\
\text { access. }\end{array}$ & $\begin{array}{l}\text { Ipswich City } \\
\text { Council Staff } \\
\text { Coordination }\end{array}$ & & & & $\begin{array}{l}\text { Quarterly } \\
\text { monitoring by } \\
\text { Council \& Carer } \\
\text { Groups. } \\
\text { >37-degree days } \\
\text { - brief checks. } \\
\text { Forecasted hot } \\
\text { weather, } \\
\text { monitored at } \\
\text { least once a week } \\
\text { / few days before } \\
\text { to gauge camp } \\
\text { composition, } \\
\text { numbers, roost } \\
\text { and retreat areas. }\end{array}$ & $\begin{array}{l}\text { Investigate } \\
\text { buffering activities } \\
\text { immediately } \\
\text { adjoining. }\end{array}$ \\
\hline Bundamba & $\begin{array}{l}\text { Potential } \\
\text { Spray } \\
\text { Intervention } \\
\text { - somewhat } \\
\end{array}$ & Access difficult & $\begin{array}{l}\text { Ipswich City } \\
\text { Council Staff } \\
\text { Coordination }\end{array}$ & & & & $\begin{array}{l}\text { Quarterly } \\
\text { monitoring by } \\
\text { Council \& Carer } \\
\text { Groups. }\end{array}$ & $\begin{array}{l}\text { Continue to } \\
\text { undertake mid- } \\
\text { storey tree } \\
\text { planting. }\end{array}$ & & \\
\hline
\end{tabular}


Flying-fox Disaster Response Plan 2018

\begin{tabular}{|c|c|c|c|c|c|c|c|}
\hline & $\begin{array}{l}\text { used to } \\
\text { people }\end{array}$ & & & & $\begin{array}{l}>37 \text {-degree days } \\
\text { - brief checks. } \\
\text { Forecasted hot } \\
\text { weather, } \\
\text { monitored at } \\
\text { least once a week } \\
\text { / few days before } \\
\text { to gauge camp } \\
\text { composition, } \\
\text { numbers, roost } \\
\text { and retreat areas. }\end{array}$ & & \\
\hline Woodend & $\begin{array}{l}\text { Private } \\
\text { Landholder }\end{array}$ & $\begin{array}{l}\text { Potential Spray } \\
\text { Intervention }\end{array}$ & & $\begin{array}{l}\text { Ipswich City } \\
\text { Council Staff } \\
\text { Coordination }\end{array}$ & $\begin{array}{l}\text { Water available } \\
\text { from house }\end{array}$ & $\begin{array}{l}\text { Quarterly } \\
\text { monitoring by } \\
\text { Council \& Carer } \\
\text { Groups. } \\
>37 \text {-degree days } \\
\text { - brief checks. } \\
\text { Forecasted hot } \\
\text { weather, } \\
\text { monitored at } \\
\text { least once a week } \\
\text { / few days before } \\
\text { to gauge camp } \\
\text { composition, } \\
\text { numbers, roost } \\
\text { and retreat areas. }\end{array}$ & $\begin{array}{l}\text { Revegetation of } \\
\text { mid-storey and } \\
\text { canopy. }\end{array}$ \\
\hline Camira & & $\begin{array}{l}\text { Potential Spray } \\
\text { Intervention- } \\
\text { however can be } \\
\text { flighty }\end{array}$ & Good access & $\begin{array}{l}\text { Ipswich City } \\
\text { Council Staff } \\
\text { Coordination }\end{array}$ & & $\begin{array}{l}\text { Quarterly } \\
\text { monitoring by } \\
\text { Council \& Carer } \\
\text { Groups. } \\
\text { > 37-degree days } \\
\text { - brief checks. } \\
\text { Forecasted hot } \\
\text { weather, } \\
\text { monitored at } \\
\text { least once a week } \\
\text { / few days before } \\
\text { to gauge camp } \\
\text { composition, } \\
\text { numbers, roost } \\
\text { and retreat areas. }\end{array}$ & $\begin{array}{l}\text { Clear access to } \\
\text { some additional } \\
\text { areas - find reliable } \\
\text { access to Sandy } \\
\text { Creek? }\end{array}$ \\
\hline Redbank & & $\begin{array}{l}\text { Potential Spray } \\
\text { Intervention- } \\
\text { however can be } \\
\text { flighty }\end{array}$ & Good access & $\begin{array}{l}\text { Ipswich City } \\
\text { Council Staff } \\
\text { Coordination }\end{array}$ & $\begin{array}{l}\text { Good } \\
\text { Relationship with } \\
\text { neighbours }\end{array}$ & $\begin{array}{l}\text { Quarterly } \\
\text { monitoring by } \\
\text { Council \& Carer } \\
\text { Groups. } \\
>37 \text {-degree days } \\
\text { - brief checks. } \\
\text { Forecasted hot } \\
\text { weather, }\end{array}$ & \\
\hline
\end{tabular}


Flying-fox Disaster Response Plan 2018

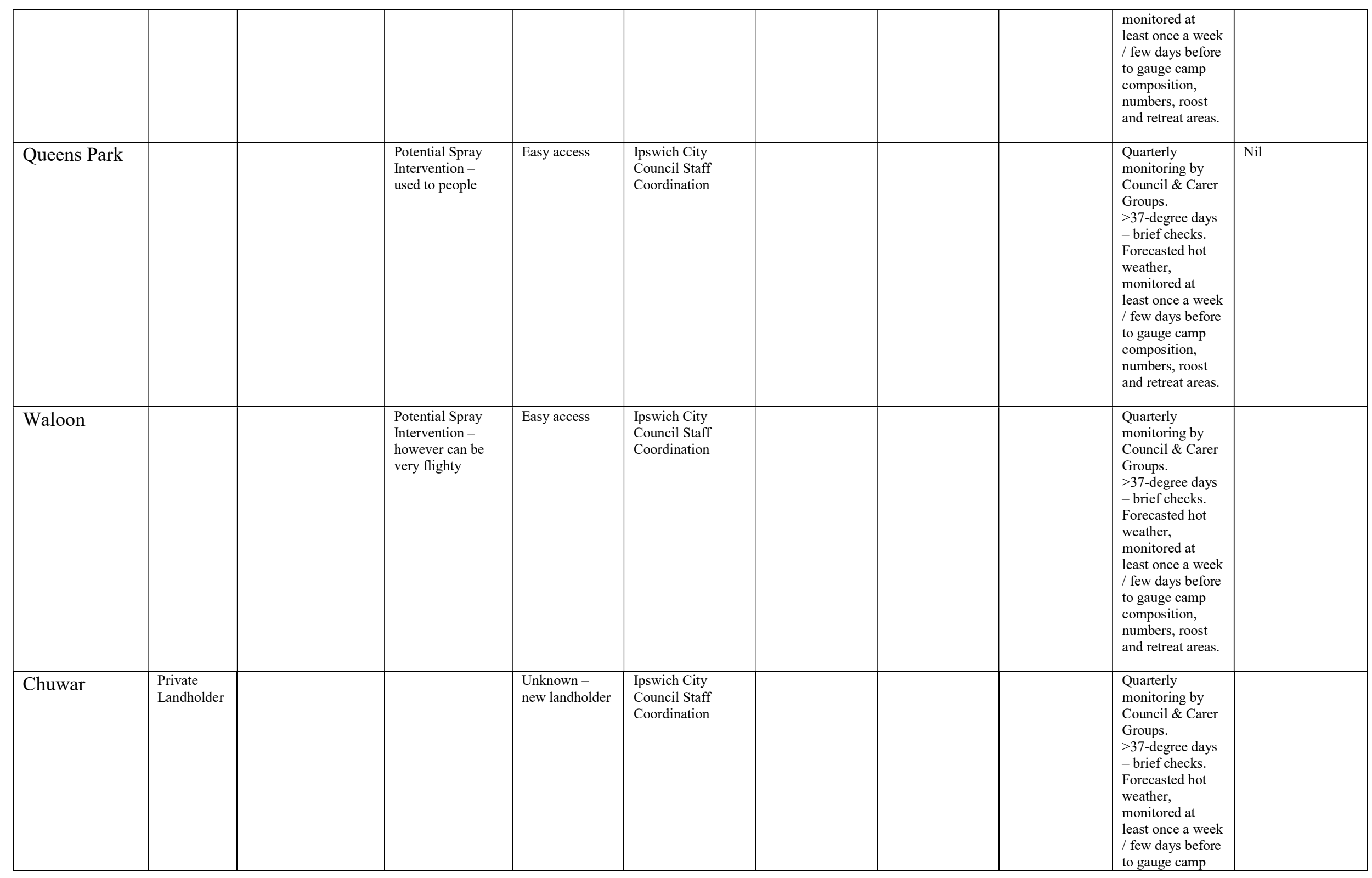


Flying-fox Disaster Response Plan 2018

\begin{tabular}{|c|c|c|c|c|c|c|c|c|c|c|}
\hline & & & & & & & & & $\begin{array}{l}\text { composition, } \\
\text { numbers, roost } \\
\text { and retreat areas. }\end{array}$ & \\
\hline \multicolumn{11}{|c|}{ SOMERSET REGIONAL COUNCIL } \\
\hline Camp & $\begin{array}{l}\text { Tenure / } \\
\text { Land } \\
\text { Manager - } \\
\text { Contact } \\
\text { Details }\end{array}$ & $\begin{array}{l}\text { Existing planning } \\
\text { and response } \\
\text { documents }\end{array}$ & $\begin{array}{l}\text { Appropriate } \\
\text { Response Action }\end{array}$ & Access & $\begin{array}{l}\text { Site Response } \\
\text { Coordination }\end{array}$ & $\begin{array}{l}\text { Principle Carer } \\
\text { Groups - First } \\
\text { Responders }\end{array}$ & $\begin{array}{l}\text { Resources } \\
\text { Available and } \\
\text { Contact Details }\end{array}$ & Site Issues & $\begin{array}{l}\text { Monitoring } \\
\text { Activities }\end{array}$ & $\begin{array}{l}\text { Alternate } \\
\text { Remediation } \\
\text { Action }\end{array}$ \\
\hline \multicolumn{11}{|l|}{ Trish has list } \\
\hline \multicolumn{11}{|c|}{ LOCKYER CITY COUNCIL } \\
\hline Camp & $\begin{array}{l}\text { Tenure / } \\
\text { Land } \\
\text { Manager - } \\
\text { Contact } \\
\text { Details }\end{array}$ & $\begin{array}{l}\text { Existing planning } \\
\text { and response } \\
\text { documents }\end{array}$ & $\begin{array}{l}\text { Appropriate } \\
\text { Response Action }\end{array}$ & Access & $\begin{array}{l}\text { Site Response } \\
\text { Coordination }\end{array}$ & $\begin{array}{l}\text { Principle Carer } \\
\text { Groups - First } \\
\text { Responders }\end{array}$ & $\begin{array}{l}\text { Resources } \\
\text { Available and } \\
\text { Contact Details }\end{array}$ & Site Issues & $\begin{array}{l}\text { Monitoring } \\
\text { Activities }\end{array}$ & $\begin{array}{l}\text { Alternate } \\
\text { Remediation } \\
\text { Action }\end{array}$ \\
\hline \multicolumn{11}{|l|}{ Trish has list } \\
\hline \multicolumn{11}{|c|}{ SCENIC RIM REGIONAL COUNCIL } \\
\hline Camp & $\begin{array}{l}\text { Tenure / } \\
\text { Land } \\
\text { Manager - } \\
\text { Contact } \\
\text { Details }\end{array}$ & $\begin{array}{l}\text { Existing planning } \\
\text { and response } \\
\text { documents }\end{array}$ & $\begin{array}{l}\text { Appropriate } \\
\text { Response Action }\end{array}$ & Access & $\begin{array}{l}\text { Site Response } \\
\text { Coordination }\end{array}$ & $\begin{array}{l}\text { Principle Carer } \\
\text { Groups - First } \\
\text { Responders }\end{array}$ & $\begin{array}{l}\text { Resources } \\
\text { Available and } \\
\text { Contact Details }\end{array}$ & Site Issues & $\begin{array}{l}\text { Monitoring } \\
\text { Activities }\end{array}$ & $\begin{array}{l}\text { Alternate } \\
\text { Remediation } \\
\text { Action }\end{array}$ \\
\hline Trish has list & & & & & & & & & & \\
\hline
\end{tabular}




\subsection{HEAT STRESS DATA RECORDING}

If number of personnel available allow, data recording of triage measures taken, and responses will give invaluable data to assist in future responses. Fill in as much as possible. If you have been involved in a heat event, data collection greatly assists in the refining of protocols and monitoring population effects. Add as much information as you feel you can. If you feel you cannot confidently separate the species by age and/or by sex then the total number, or the number for each species, still provides very important information.

\begin{tabular}{|c|c|}
\hline \multicolumn{2}{|l|}{ COLONY: } \\
\hline Date: & \\
\hline Time: & \\
\hline $\begin{array}{l}\text { Recorder (Name and Ph } \\
\text { Number) }\end{array}$ & \\
\hline $\begin{array}{l}\text { Temperature and } \\
\text { relative humidity }\end{array}$ & \\
\hline $\begin{array}{l}\text { Location (include map } \\
\text { on separate sheet if } \\
\text { possible): }\end{array}$ & \\
\hline $\begin{array}{l}\text { Characteristics of site: } \\
\text { (including vegetation structure } \\
\text { (complete / incomplete), recent } \\
\text { disturbances access to water and } \\
\text { any other relevant information) }\end{array}$ & \\
\hline $\begin{array}{l}\text { Details of heat stress } \\
\text { event: } \\
\text { (including any recorded } \\
\text { temperatures, relative humidity } \\
\text { and behavioural observations) } \\
\text { Please note if you have related } \\
\text { video footage / photographs }\end{array}$ & \\
\hline $\begin{array}{l}\text { Details of methods or } \\
\text { management } \\
\text { approaches used } \\
\text { during the heat stress } \\
\text { event. (i.e. monitoring } \\
\text { and collecting only; } \\
\text { active spraying etc) } \\
\text { Also note any responses - } \\
\text { positive or negative } \\
\text { This will help to modify future } \\
\text { responses. } \\
\text { NB (note if Video or } \\
\text { photographic footage available) }\end{array}$ & \\
\hline Observer name: & \\
\hline
\end{tabular}




\begin{tabular}{|l|l|}
\hline Phone: & \\
\hline Email: & \\
\hline
\end{tabular}

\begin{tabular}{|c|c|c|c|}
\hline \multicolumn{4}{|l|}{ ALIVE } \\
\hline \multicolumn{4}{|l|}{$\begin{array}{l}\text { Estimated total number } \\
\text { of flying-foxes present: }\end{array}$} \\
\hline $\begin{array}{l}\text { Estimated number of } \\
\text { flying-foxes present by } \\
\text { species: }\end{array}$ & Grey-headed & Black & Little Red \\
\hline \multicolumn{4}{|l|}{$D E A D$} \\
\hline \multicolumn{4}{|l|}{$\begin{array}{l}\text { Estimated total number } \\
\text { of flying-foxes that } \\
\text { died/found dead: }\end{array}$} \\
\hline $\begin{array}{l}\text { Estimated number of } \\
\text { flying-foxes that died } \\
\text { /found dead / were } \\
\text { euthanised by species, } \\
\text { age and sex: }\end{array}$ & Grey-headed & Black & Little Red \\
\hline Adult females & & & \\
\hline Adult males & & & \\
\hline Juveniles & & & \\
\hline Unknown & & & \\
\hline Comments: & & & \\
\hline
\end{tabular}

\section{FLYING FOXES TAKEN INTO TRIAGE}

Estimated total number of flying-foxes triaged:

Estimated number of flying-foxes by species: 


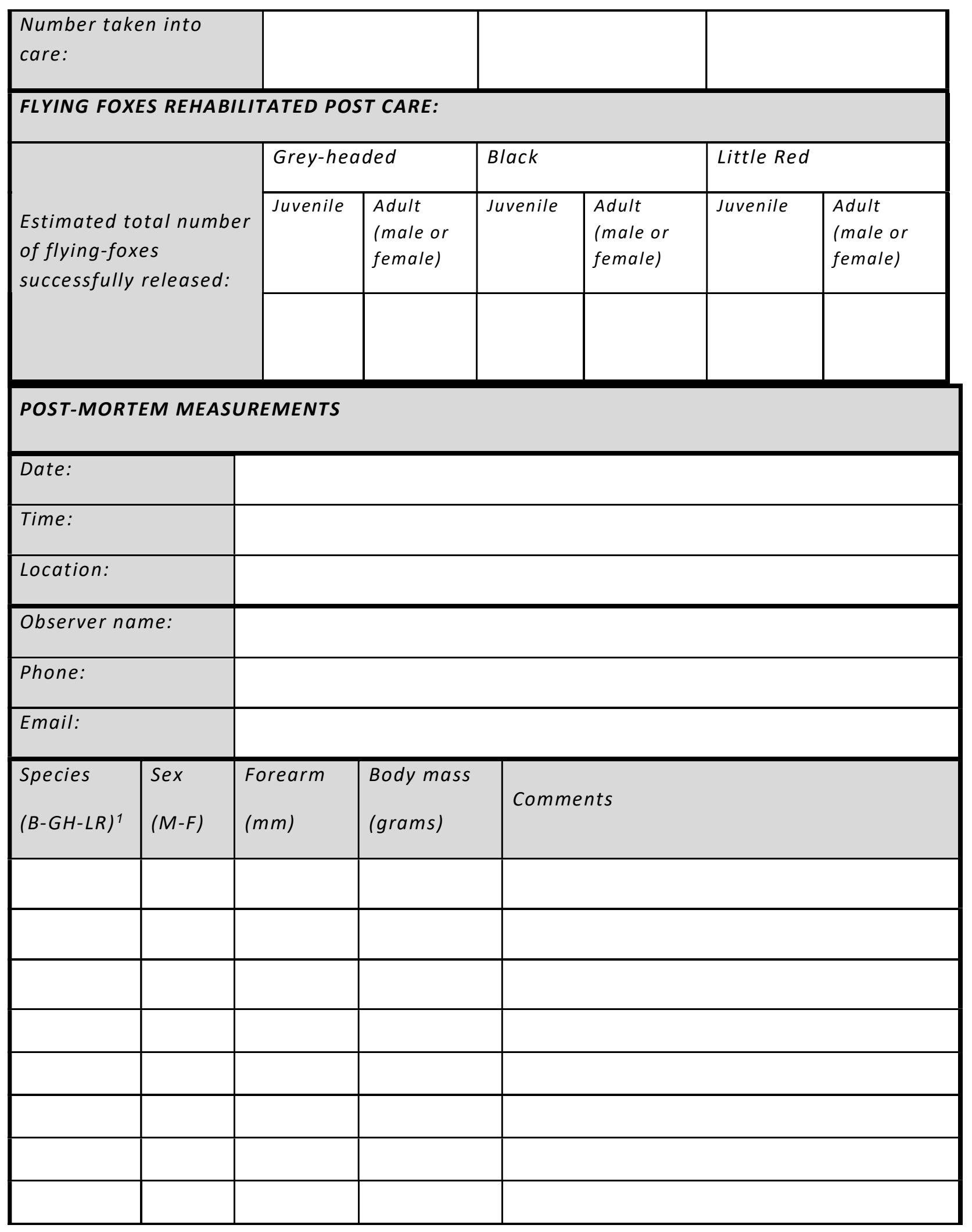

If you are experienced and qualified in taking morphometric measurements, and have taken the proper precautions, please provide details of the species, sex, forearm length and weight of

${ }^{1}$ B: Black Flying-fox, GH: Grey-headed Flying-fox, LR: Little Red Flying-fox 
individuals that died. This should be done soon after death to account for post-mortem changes in weight. If too many individuals have died to measure them all, please provide details from a representative sample.

\begin{tabular}{|l|c|}
\hline \multirow{2}{*}{$\begin{array}{l}\text { Please send a copy } \\
\text { of completed data } \\
\text { sheets to: }\end{array}$} & $\bullet \quad$ Dr. Tania Bishop, email: taniab@wildlifewarriors.org.au \\
\cline { 2 - 2 } & $\begin{array}{l}\text { Hawkesbury Institute for the Environment, UWS Hawkesbury Campus, Locked Bag 1797, } \\
\text { Penrith, NSW 2751 }\end{array}$ \\
\hline
\end{tabular}




\subsection{INDIVIDUAL OUTCOME FORMS}

\begin{tabular}{|c|c|}
\hline Bat no or ID (details) & \\
\hline $\begin{array}{l}\text { Presentation: initial temperature, } \\
\text { demeanour, hydration, other injuries } \\
\text { If euthanased - go to next bat }\end{array}$ & \\
\hline $\begin{array}{l}\text { Details of triage measures } \\
\text { - SC fluids etc } \\
\text { Also note any responses - positive or negative } \\
\text { This will help to modify future responses. } \\
\text { NB (note if Video or photographic footage available) }\end{array}$ & \\
\hline $\begin{array}{l}\text { Outcome: } \\
\text { I.e. - vet, euthanised, into care? }\end{array}$ & \\
\hline Bat no or ID (details) & \\
\hline $\begin{array}{l}\text { Presentation: initial temperature, } \\
\text { demeanour, hydration, other injuries } \\
\text { If euthanased - go to next bat }\end{array}$ & \\
\hline $\begin{array}{l}\text { Details of triage measures } \\
\text { - SC fluids etc } \\
\text { Also note any responses - positive or } \\
\text { negative } \\
\text { This will help to modify future responses. } \\
\text { NB (note if Video or photographic footage } \\
\text { available) }\end{array}$ & \\
\hline $\begin{array}{l}\text { Outcome: } \\
\text { I.e. - vet, euthanised, into care? }\end{array}$ & \\
\hline
\end{tabular}




\subsection{VOLUNTEER SIGN ON SHEET}

\section{SITE LOCATION:}

DATE:

\begin{tabular}{|c|c|c|c|c|c|c|}
\hline Name & $\begin{array}{l}\text { Vacc } \\
\text { Status }\end{array}$ & Role & Contact phone & Email & $\begin{array}{l}\text { Next of kin / } \\
\text { emergency }\end{array}$ & Time in \\
\hline & & & & & & \\
\hline & & & & & & \\
\hline & & & & & & \\
\hline & & & & & & \\
\hline & & & & & & \\
\hline & & & & & & \\
\hline & & & & & & \\
\hline & & & & & & \\
\hline & & & & & & \\
\hline & & & & & & \\
\hline & & & & & & \\
\hline & & & & & & \\
\hline & & & & & & \\
\hline & & & & & & \\
\hline & & & & & & \\
\hline & & & & & & \\
\hline & & & & & & \\
\hline & & & & & & \\
\hline & & & & & & \\
\hline & & & & & & \\
\hline & & & & & & \\
\hline & & & & & & \\
\hline & & & & & & \\
\hline & & & & & & \\
\hline & & & & & & \\
\hline & & & & & & \\
\hline
\end{tabular}




\subsection{INCIDENT REPORT}

Fill out in the event of any injury incident during the event

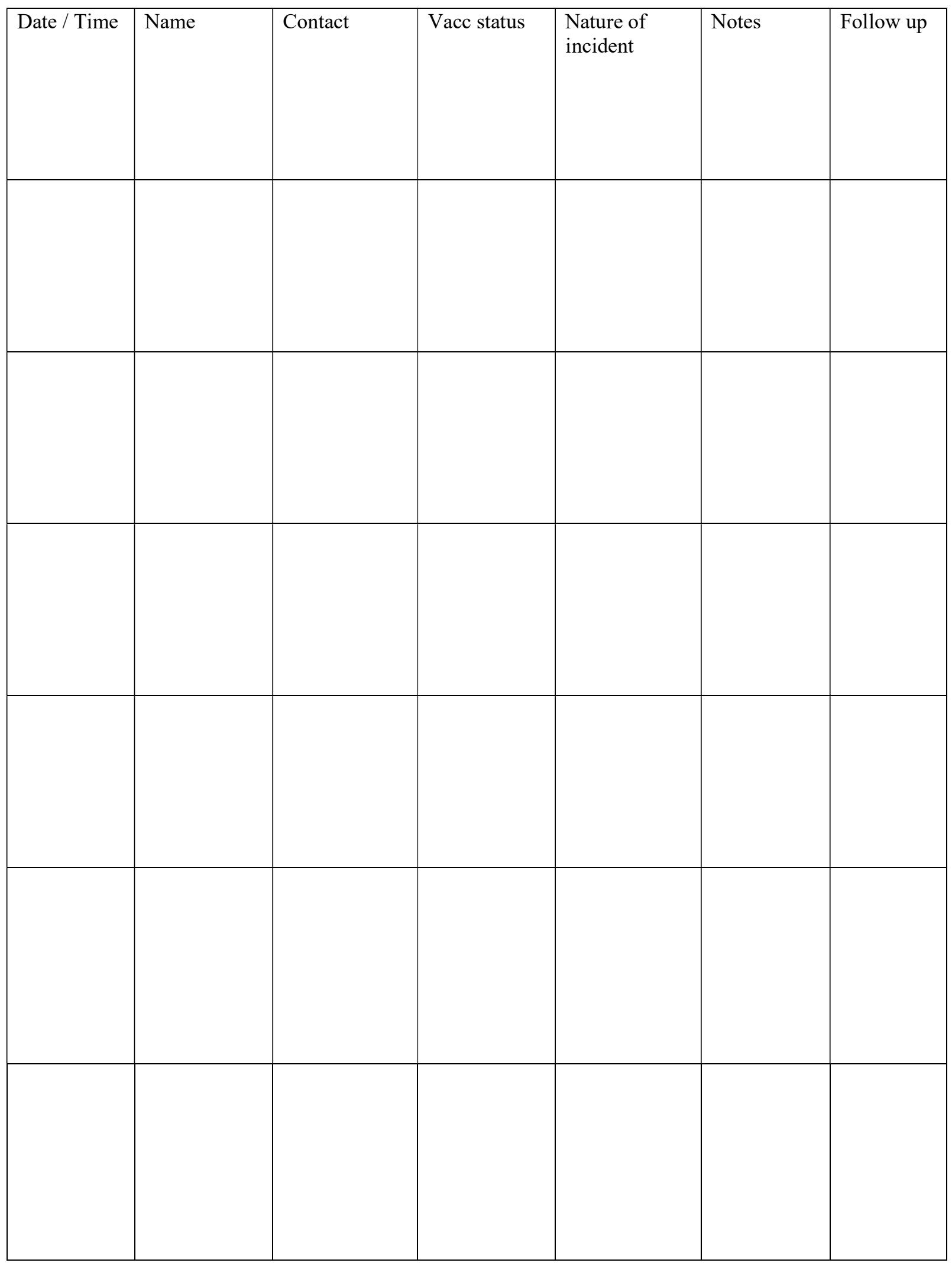




\subsection{COMMUNICATION EXAMPLE}

\section{Wildlife Heat Warning}

As you may be aware, local temperatures will be over $40^{\circ}$ this week. In such heat, our native wildlife suffers terribly.

Living near a flying fox colony, you may find bats seeking shade in your garden trees in the heat of the day. They pose no risk, but should not be touched or disturbed, and will return to their camp when it cools down.

If you find a bat injured or on the ground, please do not touch the bat, but call one of these numbers and a vaccinated wildlife rescuer will come to help you.

In the meantime, keep people and pets away, and don't try to offer any food or water.

At this time of year, any dead or injured animals may also have a baby on board.

If you have any concerns or questions you may also call these numbers for information.

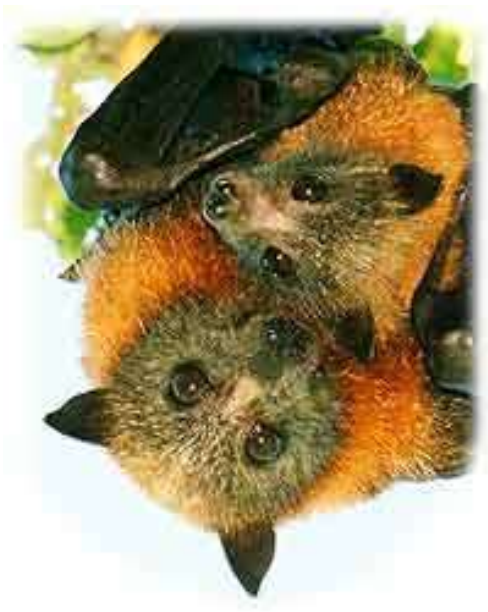

[Rescue group]

[phone number]

Australia Zoo Rescue Unit - 1300369652

RSPCA 1300264625

(1300 ANIMAL) 


\subsection{WORKSHOP QUESTIONNAIRE FOR INITIAL DATA COLLECTION}

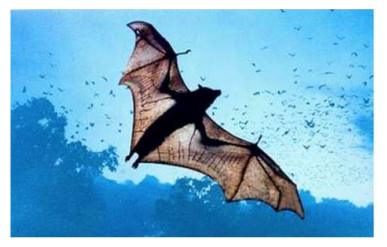

\section{SEQ HEAT EVENT PLANNING FRAMEWORK WORKSHOP}

\section{IDENTIFICATION OF HEAT STRESS EVENT (HSE) SITES}

2. How can we identify when a camp is at high risk for a HSE?

Consider the heat stress variables (and any others) and discuss their effects on prioritisation of camps in a HSE - consider these variables for camps that you are familiar with

\begin{tabular}{|l|l|l|}
\hline Weather/Climate & Camp attributes & Demographics \\
\hline $\begin{array}{l}\text { Temperature }<40^{\circ} \mathrm{C} \\
\text { No. of consecutive days }\end{array}$ & $\begin{array}{l}\text { Size of camp and history of } \\
\text { prior heat events }\end{array}$ & $\begin{array}{l}\text { Time of year - mating; pregnant } \\
\text { lactating female, pregnant females }\end{array}$ \\
\hline Humidity & $\begin{array}{l}\text { Camp composition - understory, } \\
\text { mid-storey and canopy - open / } \\
\text { closed structure }\end{array}$ & $\begin{array}{l}\text { No., age and developmental stage of } \\
\text { juveniles }\end{array}$ \\
\hline Wind direction & Proximity to water & Species composition \\
\hline $\begin{array}{l}\text { Other stressors for camp } \\
\text { e.g. camp management, food shortages }\end{array}$ & Topography / aspect / altitude & \\
\hline & Location & \\
\hline & & \\
\hline & & \\
\hline & & \\
\hline & & \\
\hline & & \\
\hline
\end{tabular}

\section{SITE MONITORING \& INFORMATION DISSEMINATION}

3. What resources are available for camp monitoring leading up to and during heat events?

- Should we be considering monitoring camps at regular intervals throughout the year to gain an understanding of camp behaviours?

- How regularly should we monitor camps directly during heat event season?

- Do we have adequate members of our teams educated in reading camp and flying fox behaviours?

- What other aides are available to help monitor and how often should we use all of these methods? E.g. - Bureau of Meteorology (BOM); Flying-fox Heat Stress Forecaster, Weather zone, data loggers in camps?

4. What are the behavioural changes of a flying-fox suffering from heat stress / heat stroke? 
- When and how should we intervene physiologically?

- Who is authorised to retrieve and treat flying-foxes?

\begin{tabular}{|l|l|l|}
\hline Behaviour & Description & Response \\
\hline Wing fanning & & \\
\hline Shade seeking & & \\
\hline $\begin{array}{l}\text { Clustering / } \\
\text { clumping }\end{array}$ & & \\
\hline Licking & & \\
\hline Salivating & & \\
\hline Panting & & \\
\hline Falling from tress & & \\
\hline $\begin{array}{l}\text { Bats on ground / } \\
\text { disorientated }\end{array}$ & & \\
\hline $\begin{array}{l}\text { Seizing / non- } \\
\text { responsive }\end{array}$ & & \\
\hline Deceased & & \\
\hline
\end{tabular}

\section{Communication}

- How can we best disseminate information AS A SEQ HEAT EVENT RESPONSE GROUP?

- How do we best keep communication lines open, supportive and constructive leading up to, during and after heat events?

- What are important components of a communication plan for media and surrounding community?

- Social media - ? - alert when heat stress forecasters and BOM are indicating heat events are likely - Monitor local camps directly and communicate behaviours

- How do we effectively trigger to entire groups that preparation needs to start?

\section{RESPONSE ACTIVITIES}

6. The human aspect of responding to heat events - WH\&S (Physical \& Emotional) 
- What WH\&S Procedures Need to be in place?

- Council WH\&S requirements for operations on Council Property?

- HSE's are stressful and emotive. The emotional toll on all parties responding to a heat event is grossly underestimated.

- How do we support the people involved in these events?

\section{HSE Response Logistics}

- Each camp is unique, however the HSE operative should be the same. What on-site features need to be identified at a HSE site? What equipment needs to be on standby?

\begin{tabular}{|l|l|}
\hline Feature & Details \\
\hline Access & Tenure, locked gates, parking, footpaths or tracks, no-go zones, maps \\
\hline Health and safety & $\begin{array}{l}\text { Headquarters / operative tent, inductions, sign in-out sheets, first aid, drinking } \\
\text { water, wash station, PPE. } \\
\text { Any amenities? }\end{array}$ \\
\hline Available resources & Water, power \\
\hline Rescue and care & Triage area, rescue / transport access and process \\
\hline Drivers & Animals to wildlife hospitals / carers \\
\hline $\begin{array}{l}\text { Existing planning and } \\
\text { response documentation }\end{array}$ & \\
\hline & \\
\hline & \\
\hline & \\
\hline & \\
\hline & \\
\hline
\end{tabular}


8. What resources do we need to have ready and available to effectively respond to a heat event AND How do we enact their availability?

\begin{tabular}{|l|l|}
\hline Resource & Enaction \\
\hline Shade & \\
\hline Water & \\
\hline PPE i.e. & \\
\hline Protective clothing & \\
\hline Ice vets & \\
\hline Triage equipment i.e. & \\
\hline Battery operated fans & \\
\hline Body disposal & \\
\hline & \\
\hline & \\
\hline & \\
\hline & \\
\hline & \\
\hline & \\
\hline
\end{tabular}

\section{Roles}

- $\quad$ Successful HSE responses require many and varied roles requiring differing skill and fitness levels.

- What roles do we need to ensure we have covered at each HSE site?

\begin{tabular}{|l|l|l|}
\hline Roles & Responsibility & $\begin{array}{c}\text { Who? (e.g. Council, carers, } \\
\text { vets, community, business) }\end{array}$ \\
\hline Safety officer & & \\
\hline Communication & & \\
\hline Colony monitors & & \\
\hline Induction / scribe / data recorder & & \\
\hline Coordination & & \\
\hline Rescue & & \\
\hline Spraying & & \\
\hline Triage and post triage monitoring & & \\
\hline Body removal & & \\
\hline Euthanasia / drug licence & & \\
\hline Drivers & & \\
\hline Carers on standby & & \\
\hline Set up and pack up & & \\
\hline Food, water provision & & \\
\hline Human first aid & & \\
\hline & & \\
\hline & & \\
\hline & & \\
\hline & & \\
\hline
\end{tabular}




\section{HSE REPORTING}

10. Data has the capacity to better frame our responses to HSE's as well as to provide valuable information on the effect of HSE's on the flying-fox population as a whole.

- How can we improve out data reporting during HSE's?

- Who should we be reporting this data to?

- What data is important and why?

\section{COMMUNITY ENGAGEMENT \& COMMUNICATION}

\section{Community Engagement}

- How can we more effectively communicate and engage with the local community in the lead up to heat events in order to allay fears but also ensure that they don't enter or handle heat affected bats?

- How do we best respond to media and members of the surrounding community? 


\section{SUBREGIONAL RESPONSES}

\section{HSE Prone Camps \& Appropriate Response Action}

- Which camps have historically had HSE and which NEW camps may be of concern?

- Based on the individual characteristics of each camp - i.e. demeanour of bats; accessibility; local resources; camp structure and vegetation, what are appropriate intervention methods for managing heat stress?

i.e.; water truck/ute sprayers; shade provision; backpack spraying; no intervention until late stages, as bats are too unaccustomed to human presence?

\begin{tabular}{|l|l|}
\hline Camp & Appropriate Response Action \\
\hline & \\
\hline & \\
\hline & \\
\hline & \\
\hline & \\
\hline & \\
\hline
\end{tabular}

\section{Monitoring}

- Monitoring options: include remote camera options also

\begin{tabular}{|l|l|l|}
\hline Camp & Monitoring Options & Who? \\
\hline & & \\
\hline & & \\
\hline & & \\
\hline & & \\
\hline & & \\
\hline & & \\
\hline
\end{tabular}




\section{Communication}

- Who, how and when?

\begin{tabular}{|l|l|l|}
\hline Who & How & When \\
\hline Landholder & & \\
\hline $\begin{array}{l}\text { Resource Providers } \\
\text { (E.g. water trucks etc) }\end{array}$ & & \\
\hline $\begin{array}{l}\text { Carer Groups \& Support } \\
\text { People }\end{array}$ & & \\
\hline Wildlife Hospitals & & \\
\hline $\begin{array}{l}\text { Reporting- HSE Website, } \\
\text { Local Councils etc } \\
\bullet . . .\end{array}$ & & \\
$\bullet \quad$. & & \\
\hline & & \\
\hline & & \\
\hline
\end{tabular}

\section{Site Logistics}

○ Camp:

\begin{tabular}{|l|l|l|}
\hline Feature & Details & Notes \\
\hline Access & $\begin{array}{l}\text { Tenure, locked gates, parking, } \\
\text { footpaths or tracks, no-go zones, maps }\end{array}$ & \\
\hline Health and safety & $\begin{array}{l}\text { Headquarters / operative tent, } \\
\text { inductions, sign in-out sheets, first aid }\end{array}$ & \\
\hline Available resources & Water, power & \\
\hline Rescue and care & Triage area, rescue / transport access & \\
\hline Drivers & Animals to wildlife hospitals / carers & \\
\hline $\begin{array}{l}\text { Existing planning } \\
\text { and response } \\
\text { documents }\end{array}$ & & \\
\hline & & \\
\hline & & \\
\hline & & \\
\hline
\end{tabular}

Site Logistics

○ Camp:

\begin{tabular}{|l|l|l|}
\hline Feature & Details & Notes \\
\hline Access & $\begin{array}{l}\text { Tenure, locked gates, parking, } \\
\text { footpaths or tracks, no-go zones, maps }\end{array}$ & \\
\hline Health and safety & $\begin{array}{l}\text { Headquarters / operative tent, } \\
\text { inductions, sign in-out sheets, first aid }\end{array}$ & \\
\hline Available resources & Water, power & \\
\hline Rescue and care & Triage area, rescue / transport access & \\
\hline Drivers & Animals to wildlife hospitals / carers & \\
\hline
\end{tabular}




\begin{tabular}{|l|l|l|}
\hline $\begin{array}{l}\text { Existing planning } \\
\text { and response } \\
\text { documents }\end{array}$ & & \\
\hline & & \\
\hline & & \\
\hline & & \\
\hline & & \\
\hline
\end{tabular}

\section{Site Logistics}

○ Camp:

\begin{tabular}{|l|l|l|}
\hline Feature & Details & Notes \\
\hline Access & $\begin{array}{l}\text { Tenure, locked gates, parking, } \\
\text { footpaths or tracks, no-go zones, maps }\end{array}$ & \\
\hline Health and safety & $\begin{array}{l}\text { Headquarters / operative tent, } \\
\text { inductions, sign in-out sheets, first aid }\end{array}$ & \\
\hline Available resources & Water, power & \\
\hline Rescue and care & Triage area, rescue / transport access & \\
\hline Drivers & Animals to wildlife hospitals / carers & \\
\hline $\begin{array}{l}\text { Existing planning } \\
\text { and response } \\
\text { documents }\end{array}$ & & \\
\hline & & \\
\hline & & \\
\hline & & \\
\hline
\end{tabular}

16. Response Resources and Availability (equipment and human resources)

○ Camp:

\begin{tabular}{|l|l|}
\hline Resource & Enaction \\
\hline Shade & \\
\hline Water & \\
\hline PPE - & \\
\hline Protective clothing - & \\
\hline Ice vets & \\
\hline Triage equipment - & \\
\hline Battery operated fans & \\
\hline Water & \\
\hline Body disposal & \\
\hline & \\
\hline & \\
\hline & \\
\hline & \\
\hline & \\
\hline
\end{tabular}

\section{○ Camp:}

\begin{tabular}{|l|}
\hline Resource \\
\hline Shade \\
\hline Water \\
\hline PPE - \\
\hline Protective clothing - \\
\hline Ice vets \\
\hline Triage equipment - \\
\hline Battery operated fans \\
\hline
\end{tabular}

Enaction 


\begin{tabular}{|l|l|}
\hline Water & \\
\hline Body disposal & \\
\hline & \\
\hline & \\
\hline & \\
\hline & \\
\hline
\end{tabular}

\section{○ Camp:}

\begin{tabular}{|l|l|}
\hline Resource & Enaction \\
\hline Shade & \\
\hline Water & \\
\hline PPE - & \\
\hline Protective clothing - & \\
\hline Ice vets & \\
\hline Triage equipment - & \\
\hline Battery operated fans & \\
\hline Water & \\
\hline Body disposal & \\
\hline & \\
\hline & \\
\hline & \\
\hline
\end{tabular}

\section{Alternate remediation actions for Camps}

- Camp habitat structure improvements, installation of sprinklers etc

\begin{tabular}{|l|l|}
\hline Camp & Alternate Remediation Action \\
\hline & \\
\hline & \\
\hline & \\
\hline & \\
\hline & \\
\hline
\end{tabular}




\subsection{ABLV AND FLYING-FOX HANDLING}

https://www.worksafe.qld.gov.au/ data/assets/pdf file/0003/82902/lyssavirus-handlingbats.pdf

Please add in printed versions

\subsection{LIVING WITH FLYING}

https://www.logan.qld.gov.au/ data/assets/pdf file/0013/333031/DEHP Living-near-flyingfoxes-fact-sheet.pdf

Please add in printed versions 